\title{
Holocene glacier activity reconstructed from proglacial lake Gjøavatnet on Amsterdamøya, NW Svalbard
}

Authors: Gregory A. de Wet ${ }^{1 *}$, Nicholas L. Balascio ${ }^{2}$, William J. D’Andrea ${ }^{3}$, Jostein Bakke ${ }^{4}$, Raymond S. Bradley ${ }^{1}$, Bianca Perren ${ }^{5}$

${ }^{1}$ Department of Geosciences, University of Massachusetts Amherst, Amherst MA 01003 USA

${ }^{2}$ Department of Geology, College of William \& Mary, Williamsburg, VA 23187 USA

${ }^{3}$ Lamont-Doherty Earth Observatory of Columbia University, Palisades, NY, 10964, USA

${ }^{4}$ Department of Earth Science, University of Bergen, Bergen, 5007, Norway

${ }^{5}$ British Antarctic Survey, Cambridge CB3 OET, United Kingdom
*Corresponding Author. Tel: +1 7177252604

Email address: gdewet@geo.umass.edu (G. de Wet)

\section{Keywords:}

Holocene Paleoclimate, Svalbard, Lake Sediments, Glaciers, Fram Strait, Freshwater Forcing 


\section{Abstract}

Well-dated and highly resolved paleoclimate records from high latitudes allow for a better understanding of past climate change. Lake sediments are excellent archives of environmental change, and can record processes occurring within the catchment, such as the growth or demise of an upstream glacier. Here we present a Holocene-length, multi-proxy lake sediment record from proglacial lake Gjøavatnet on the island of Amsterdamøya, northwest Svalbard. Today, Gjøavatnet receives meltwater from the Annabreen glacier and contains a record of changes in glacier activity linked to regional climate conditions. We measured changes in organic matter content, dry bulk density, bulk carbon isotopes, elemental concentrations via Itrax core-scanning, and diatom community composition to reconstruct variability in glacier extent back through time. Our reconstruction indicates that glacially derived sedimentation in the lake decreased markedly at $\sim 11.1 \mathrm{cal}$ kyr BP, although a glacier likely persisted in the catchment until $~ 8.4$ cal kyr BP. During the mid-Holocene ( 8.4-1.0 cal kyr BP) there was significantly limited glacial influence in the catchment and enhanced deposition of organic-rich sediment in the lake. The deposition of organic rich sediments during this time was interrupted by at least three multi-centennial intervals of reduced organic matter accumulation $(\sim 5.9-5.0,2.7-2.0$, and 1.7-1.5 cal kyr BP). Considering the chronological information and a sedimentological comparison with intervals of enhanced glacier input, we interpret these intervals not as glacial advances, but rather as cold/dry episodes that inhibited organic matter production in the lake and surrounding catchment. At $\sim 1.0$ cal kyr BP, input of glacially derived sediment to Gjøavatnet abruptly increased, representing the rapid expansion of the Annabreen glacier.

1 2 3 4

\section{1) Introduction}


Reliable and highly resolved paleoclimate reconstructions are necessary in order to better contextualize recent and predicted climate change (Kaplan and Wolfe, 2006), especially from high latitudes where these changes are expected to be greatest (Callaghan et al., 2010; Serreze and Barry, 2011; Stocker et al., 2013). Glaciers and small ice caps respond rapidly to climate variations, but direct evidence for past changes in ice extent in remote areas is temporally and spatially limited. The Holocene Epoch (past $~ 11.7$ thousand calendar years before present (cal kyr BP)) provides important context to understand Arctic climate dynamics because atmospheric and ocean circulation patterns were similar to their current configuration and natural insolation forcing caused widespread environmental change without the overprint of significant anthropogenic influence (until recent decades) (Johnsen et al., 2001; Kaufman et al., 2004; Mayewski et al., 2004). Broad scale Arctic climate throughout this interval is understood to have been characterized by early Holocene warmth that progressively transitioned toward a colder late Holocene (i.e., the Neoglacial), driven mainly by declining high latitude summer insolation (Laskar et al., 2004; Miller et al., 2010; Briner et al., 2016). Superimposed on this trend are spatial heterogeneities linked to the decaying Northern Hemisphere ice sheets and associated meltwater pulses (e.g. Sejrup et al., 2016). High-resolution paleoclimate records are important to better examine the timing, expression, and magnitude of Holocene climate change throughout the Arctic. Atlantic and the Arctic Ocean basins (Figure 1). Near Svalbard, warm Atlantic Water transported via the West Spitsbergen Current (WSC) mixes with cold, less saline water from the Arctic Ocean. Atmospheric conditions are influenced by the relative influence of cold, polar-derived air masses from the north and east and warmer subpolar maritime air masses from the south and south west (Førland et al., 2011). The relative locations of these important boundaries, along with associated sea ice feedbacks, has been shown to vary throughout the Holocene and influence climate in Svalbard (e.g Müller et al., 2012; Rasmussen et al., 2014; Werner et al., 2013, 2015).

Broadly, evidence from marine records near Svalbard and in the northern North Atlantic suggests 91 a warm early Holocene period ( 11-8 kyr BP), characterized by an increased flux of Atlantic water to 
high latitudes (Aagaard-Sørensen et al., 2014; Forwick and Vorren, 2009; Hald et al., 2004, 2007; Müller et al., 2012; Rasmussen et al., 2014; Risebrobakken et al., 2011; Sarnthein et al., 2003; Skirbekk et al., 2010; Ślubowska et al., 2005; Werner et al., 2013, 2015). The transition to cooler (Neoglacial) conditions during the middle Holocene is not well constrained, with some records suggesting cooling began as early 8.8 cal kyr BP (e.g. Hald et al., 2004), while others point to cooling beginning $\sim 6$ kyr BP (e.g. Rasmussen et al., 2014). Oceanic conditions near Svalbard during the late Holocene are generally characterized by cold temperatures overprinted by fluctuations linked to changes in the advection of warm Atlantic Water in the WSC (e.g. Aagaard-Sørensen et al., 2014; Berben et al., 2014; Ślubowska et al., 2005; Werner et al., 2013).

While there has been an increase in the number of terrestrial Holocene paleoclimate studies from Svalbard in recent years (e.g. D’Andrea et al., 2012; Reusche et al., 2014; Røthe et al., 2015; van der Bilt et al., 2015; van der Bilt et al., 2016; Gjerde et al., in press; Balascio et al., in press), this region generally lacks continuous, well-dated paleoenvironmental reconstructions. Retreat of the Barents Sea ice sheet had begun during the end of the Pleistocene ( 20-14 cal kyr BP) (Gjermundsen et al., 2013; Hormes et al., 2013; Ingólfsson and Landvik, 2013), and numerous records suggest many smaller glaciers in Svalbard retreated or completely melted during the early Holocene (Reusche et al., 2014; Røthe et al., 2015; Snyder et al., 2000; Svendsen and Mangerud, 1997; van der Bilt et al., 2015). The timing of late-Holocene glacial re-advance however, remains poorly constrained; some studies suggest glaciers advanced $~ 3-4$ cal kyr BP (Reusche et al., 2014; Røthe et al., 2015; Svendsen and Mangerud, 1997), while others point to a later advance closer to 1 cal kyr BP (Humlum et al., 2005; Snyder et al., 2000; van der Bilt et al., 2015). Here we present a glaicer reconstruction from proglacial lake Gjøavatnet on the island of Amsterdamøya in NW Svalbard spanning the Holocene (Figure 1). The objective of this study is to reconstruct the history of the upstream Annabreen glacier (Figure 1) towards a better understanding of Holocene climate change in the region. The maritime climate of Amsterdamoya, and the presence of a glacier in the Gjoavatnet catchment, makes this record valuable for addressing questions about past climate variations in the High Arctic North Atlantic. Our record suggests that Annabreen disappeared or 
was dramatically reduced in size by $\sim 8.4$ cal kyr BP. During the interval $8.4-1$ cal kyr BP, sedimentation

119 in the lake was marked by higher amounts of organic material accumulation, but was punctuated by

120 multi-centennial-length periods with relatively lower organic matter content. A return to minerogenic

121 sedimentation at $1 \mathrm{cal}$ kyr BP is interpreted to represent the re-advance of Annabreen at that time.

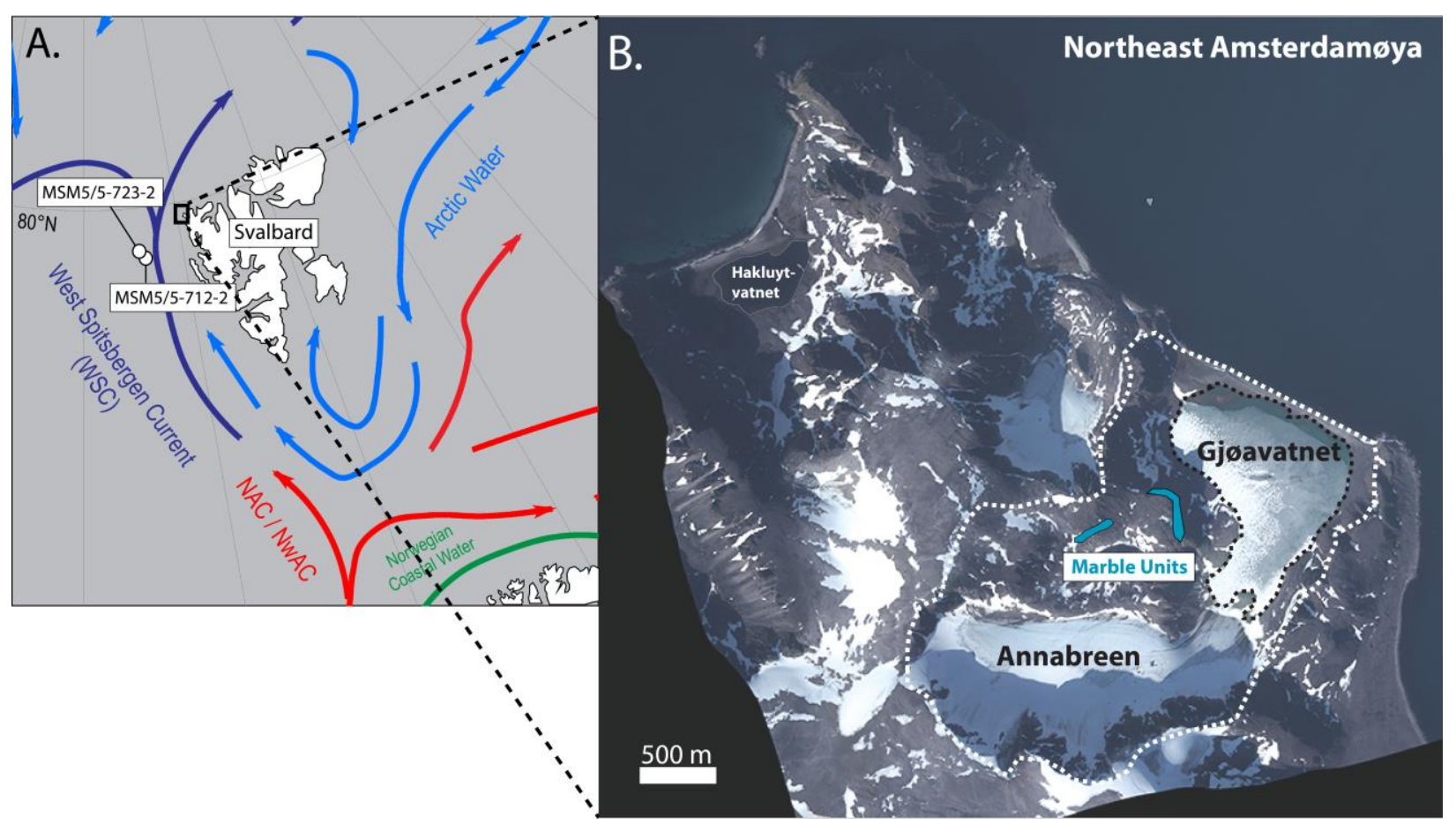

Figure 1: A) Map of Svalbard and surrounding surface currents as well as locations of marine sediment cores MSM5/5-723-2 and MSM5/5-712-2 (Werner et al., 2013; 2015); B) Aerial image of island of Amsterdamøya with Annabreen glacier and Gjøavatnet lake (this study) and Hakluytuvatnet lake (Gjerde et al., in press) labeled. Blue polygons represent the approximate locations of marble outcrops (Ohta et al., 2007). Dashed white line denotes approximate catchment of Gjøavatnet.

\section{2) Regional Setting}

Svalbard's climate is characterized by highly variable temperatures and low average annual precipitation. A meteorological station at Ny-Ålesund, $\sim 95 \mathrm{~km}$ south of Amsterdamøya, recorded average annual temperatures of $-5.2^{\circ} \mathrm{C}$ over the period $1981-2010$, though average temperatures of individual years ranged from $-12^{\circ} \mathrm{C}$ to $3.8^{\circ} \mathrm{C}$ (Førland et al., 2011). The average annual precipitation at $\mathrm{Ny}$-Ålesund is $427 \mathrm{~mm}$ (Førland et al., 2011), with the majority of moisture sourced from the south/southwest and occurring during the fall and winter months (Førland et al., 2011). The dry nature of this environment 
137 suggests that relatively small changes in the precipitation budget could play a large role in the mass

138 balance of local glaciers. There is a positive relationship between temperature and precipitation in all

139 seasons (Førland et al., 2011).

141 Study Site

142 Lake Gjøavatnet $\left(7^{\circ} 46^{\prime} 00^{\prime \prime} \mathrm{N}, 10^{\circ} 51^{\prime} 45^{\prime \prime} \mathrm{E}, 2 \mathrm{~m}\right.$ a.s.1.) is a small proglacial lake on the eastern

143 coast of Amsterdamøya, Svalbard (Figure 1). The lake catchment contains a steep-sided cirque (area of

$144 \sim 2.8 \mathrm{~km}^{2}$ ), marked by the presence of the Annabreen glacier (surface area of $0.87 \mathrm{~km}^{2}$ ), which currently

145 terminates in the southwest corner of the lake. The limited vegetation in the catchment is characterized as

146 northern Arctic tundra (Birks et al., 2004). Gjøavatnet itself has an area of $\sim 0.52 \mathrm{~km}^{2}$ and has a maximum

147 depth of $\sim 15 \mathrm{~m}$. The lake is separated from the ocean by a narrow ( $\sim 30 \mathrm{~m}$ wide) strip of bedrock (Hjelle

148 and Ohta, 1974; Ohta et al., 2007), which is currently covered with large numbers of smoothed boulders

149 and driftwood (Figure 1). There has been no net postglacial uplift relative to sea level in the immediate

150 region during the Holocene (Forman, 1990; Landvik et al., 1998; 2003). The surrounding bedrock is

151 comprised mainly of Mesoproterozoic banded gneiss and migmatite of the Smeerenburgfjorden Complex

152 containing small outcrops of marble with skarn mineralization in the northwestern part of the catchment

153 (blue outlines in Figure 1) (Hjelle and Ohta, 1974; Ohta et al., 2007).

154

155

156

157

158

159

160

161

162

163

\section{3) Methods}

\section{1) Fieldwork and Lake Coring}

Prior to coring, Gjøavatnet was surveyed using ground penetrating radar (GPR) as well as a Lowrance sonar bathymetric device to determine lake bottom bathymetry and soft sediment distribution (Figure 2). GPR profiles were collected using a Mala RAMAC GPR unit with a 50 MHZ antenna.

Five sediment cores were collected from Gjøavatnet in the summer of 2014; 2 piston cores (GJP01-14; $210 \mathrm{~cm}$ in length, and GJP-02-14; $82 \mathrm{~cm}$ ), and 3 gravity/surface cores (GJD-01-14; $39 \mathrm{~cm}$, GJD02-14; $46 \mathrm{~cm}$, and GJD-03-14; $42 \mathrm{~cm}$ ) (Table 1) (see Figure 2 for coring locations). Surface cores were 
164 collected using a Uwitec surface corer. Piston cores were collected using a percussion piston coring

165 device and were hammered until refusal to ensure maximum sediment recovery. GJP-01-14 was cut into

166 two sections in the field ( 1 of 2: $135.5 \mathrm{~cm}$ long, 2 of 2: $71 \mathrm{~cm}$ long) to allow for transport. The sediment

167 cores were then shipped back to the University of Bergen for splitting and analysis.

Table 1: Sediment cores collected from Gjøavatnet

\begin{tabular}{|c|c|c|c|c|c|}
\hline Core Name & GJP-01-14 & GJP-02-14 & GJD-01-14 & GJD-02-14 & GJD-03-14 \\
\hline Core Type & Piston & Piston & Surface/Gravity & Surface/Gravity & Surface/Gravity \\
\hline $\begin{array}{c}\text { Core Length } \\
\text { (cm) }\end{array}$ & 206.5 & 95 & 30 & 43 & 42 \\
\hline
\end{tabular}

170

171

172

173

174

175

176

177

178

179

180 181 of most of our interpretations.

\section{2) Composite sediment record}

A composite sediment record was created based mainly on piston core GJP-01-14, which was collected from the deepest part of the lake (Figure 2) and is the longest core retrieved from Gjøavatnet (Figure 3). Comparison of both visual stratigraphy and proxy data between piston core GJP-01-14 and surface cores GJD-01-14 and GJD-02-14 (recovered from the same basin) reveal that only $2.5 \mathrm{~cm}$ of sediment were lost from the upper part of the GJP-01-14 during piston coring. The basal sediment in both piston cores (GJP-01-14 and GJP-02-14) is comprised of diamict, interpreted as glacial till, suggesting the entire Holocene record was recovered (Figure 3). To achieve the highest resolution record possible we focused our investigation on the GJP-01-14 core (206.5 cm length). Results from this core form the basis 


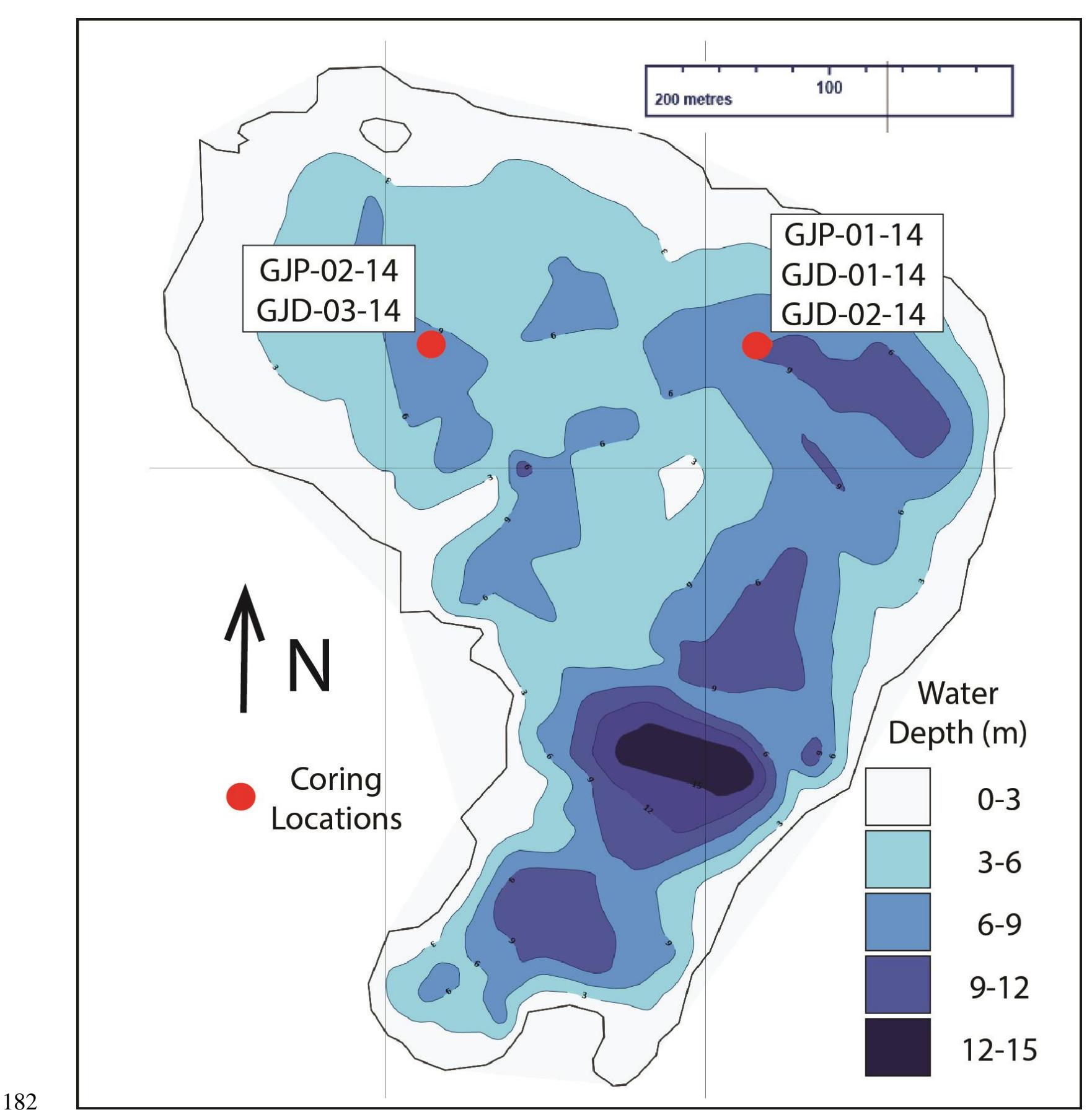

183 Figure 2: Bathymetric map of Gjøavatnet with coring sites noted by red circles. Our investigation 184 focused mainly on core GJP-01-14 from eastern basin. 


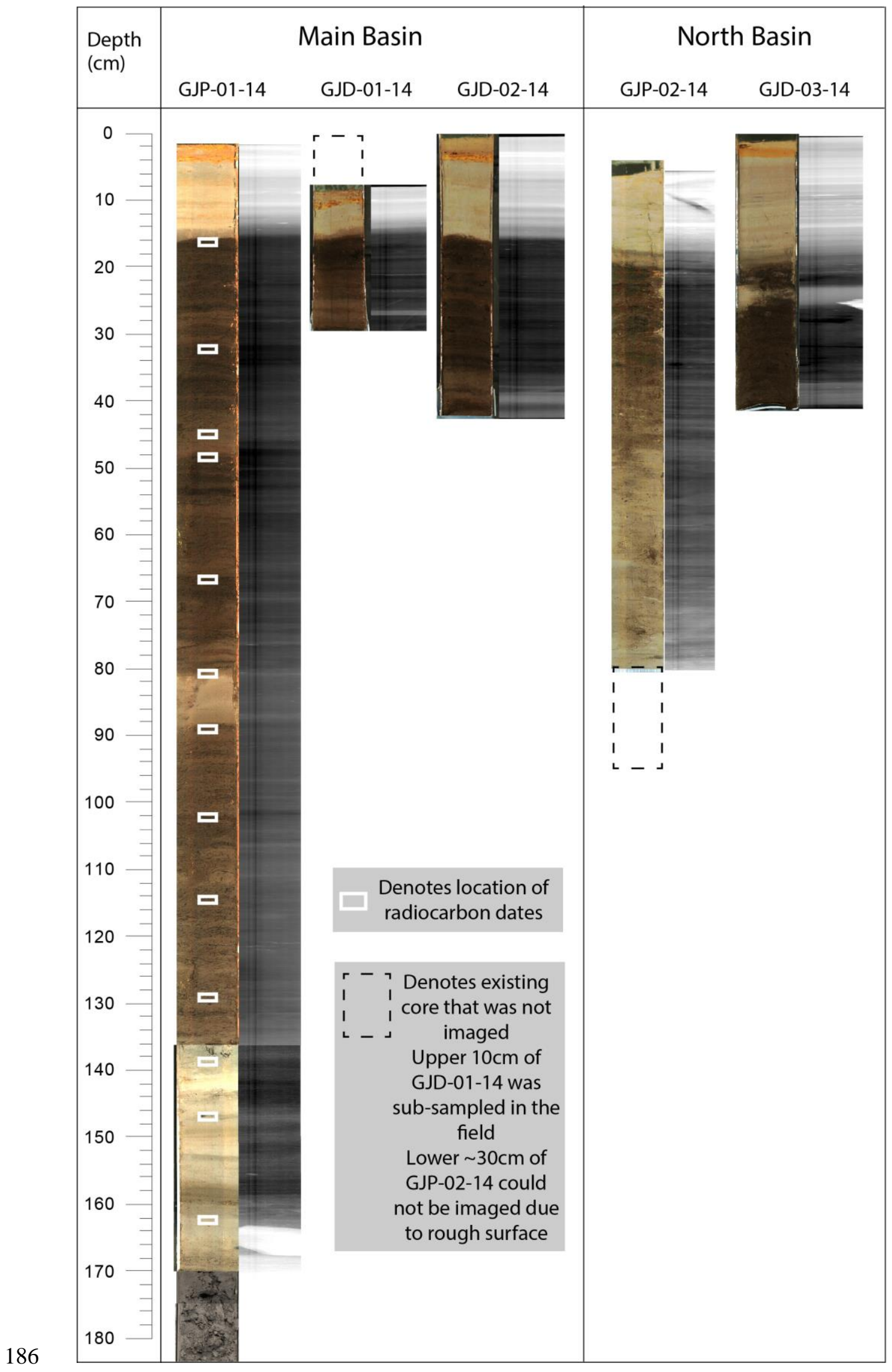


187

188

189

190

191

192

193

194

195

196

197

198

199

200

201

202

203

204

205

206

207

208

209

210

211

212

213

Figure 3: Line-scan images and x-radiographs of all cores collected from Gjøavatnet. GJP-01-14 was the focus of this investigation. Depth of radiocarbon dates are denoted with white rectangles. Dashed black lines represent existing core that could not be imaged. Lighter shades in X-radiographs represent denser material. Note that color difference in lowest portion of GJP-01-14 (section from $\sim 170-180 \mathrm{~cm}$ ) is due to simply to different lighting during imaging.

\section{3) Laboratory Analyses}

Cores were split and imaged at the University of Bergen prior to analyses. All five cores were analyzed for surface magnetic susceptilibity (MS) at $0.5 \mathrm{~cm}$ resolution using a Bartington MS2E point sensor. The cores were also analyzed using an ITRAX X-ray fluorescence (XRF) core scanner located at EARTHLAB, University of Bergen, to determine elemental concentrations. Scans were carried out using a molybdenum (Mo) tube with a downcore resolution of $200 \mu \mathrm{m}$. The voltage and current were set to 30kV and 45mA respectively, with an XRF count time of 10 seconds. For GJP-01-14, Itrax core scanning data were not collected below $167 \mathrm{~cm}$ depth because the sediment surface was too uneven for the instrument to accommodate.

GJP-01-14 was sub-sampled at $0.5 \mathrm{~cm}$ intervals for weight loss-on-ignition (LOI), dry bulk density (DBD), and water content (WC) ( $n=335$ ) (after Dean, 1974; Heiri et al., 2001). A syringe was used to ensure a constant $1 \mathrm{~cm}^{3}$ of sediment was removed. The sediment below $\sim 167 \mathrm{~cm}$ in GJP-01-14 was either too stiff to properly remove the necessary volume of sediment for accurate LOI and DBD analysis or was simply composed of large clasts, making the analyses impossible. Accordingly, the majority of our proxy data (and associated figures) do not include data from the bottom $\sim 40 \mathrm{~cm}$ of the GJP-01-14 core.

Macrofossils for radiocarbon dating were removed and sent to the Poznan Radiocarbon Laboratory in Poland for analysis (Table 2). $\delta^{13} \mathrm{C}$ values of bulk sediment $(n=50)$ were measured at the Lamont Doherty Earth Observatory using a Costech elemental combustion system (EA) coupled to a Delta V Plus IRMS (Thermo). A two-point isotope calibration curve was constructed using standards USGS40 and USGS41 to place measured values on the VPDB scale. A third standard (USGS24) was run during the period of data acquisition to evaluate the accuracy of measurement. 
Eight samples were chosen for diatom taxonomic analysis from 121.5, 135.5, 137, 149.5, 161.5,

$215163.5,164.5$, and $165.5 \mathrm{~cm}$ composite depth in GJP-01-14 to evaluate the possibility of early Holocene

216 marine incursions and to characterize lacustrine conditions. Diatoms were isolated from the sediments

217 using standard oxidative techniques modified from Renberg (1990) and mounted on glass coverslips

218 using Naphrax mounting medium. At least 300 diatom samples were identified from each slide at 1000x

219 under oil immersion and identified using predominantly Arctic diatom floras (e.g. Antoniades et al., 220 2008).

221

222

3.4) Statistical and Multivariate Analyses

Principal component analysis (PCA) and computation of correlation coefficients were carried out on 10 measured proxies using Matlab software for Windows. This included 9 geochemical element counts (Ti, K, Ca, Rb, Sr, Fe, Mn, Si, Al) from the Itrax core scanner as well as \%LOI. These elements were selected based on their high signal response on the Itrax (counts per second generally $>100$ ), their prevalence in siliclastic sediments, and previous studies that have identified them as useful for reconstructing minerogenic input from bedrock erosion (Bakke et al., 2013; Balascio et al., 2015; Røthe et al., 2015). Itrax data were smoothed using a $24 \mathrm{pt}$ running mean and resampled at $0.5 \mathrm{~cm}$ intervals to achieve comparable resolution to the LOI data. All datasets were also log-transformed prior to analysis.

\section{4) Results and Interpretations}

\section{1) Chronology}

The chronology of the composite sedimentary record is based on 13 radiocarbon dates of organic macrofossils taken from the GJP-01-14 core (Table 2). An age model was created using the Clam age modeling package (Blaauw, 2010) for the open-source software R (v. 3.0.1; R Development Core Team,

237 2013) (Figure 4). A smooth spline function was used to create the age model, with a default smoothing

238 value of 0.3 applied. Radiocarbon dates were calibrated using the terrestrial northern hemisphere

239 Intcal13.14C curve (Reimer et al., 2013). Calculated sedimentation rates in Gjøavatnet using this age 
240 model vary from a maximum of $\sim 29.8 \mathrm{~cm} / \mathrm{kyr}$ to a minimum of $\sim 8.6 \mathrm{~cm} / \mathrm{kyr}$ with an average value of

$241 \quad 14.7 \mathrm{~cm} / \mathrm{kyr}$. We also created an age model using the same parameters but with a linear interpolation

242 between data points instead of a smooth spline. We only use the linear interpolation-based age model as

243 an illustrative tool to highlight differences in sedimentation rate throughout the core, and do not use it for

244 any of our paleoclimate interpretations. We note that age estimates below a depth of $162.5 \mathrm{~cm}(11,140 \mathrm{cal}$

245 yr BP calibrated age) are based on extrapolation of the age model and therefore have unconstrained

246 uncertainty. This impacts only a small portion of our proxy data, which extends to $\sim 167 \mathrm{~cm}$, but does

247 affect our ability to accurately date the onset of lacustrine sedimentation in Gjøavatnet.

248 Table 2: Radiocarbon results from macrofossils taken from GJP-01-14 core

\begin{tabular}{|c|c|c|c|c|c|c|c|c|}
\hline Core & $\begin{array}{l}\text { Composite } \\
\text { Depth }(\mathrm{cm})\end{array}$ & $\begin{array}{l}\text { Sample } \\
\text { Material }\end{array}$ & $\begin{array}{c}\text { Sample } \\
\text { Mass (mg) }\end{array}$ & Mg Carbon & ${ }^{14} \mathrm{C}$ Age & $\begin{array}{l}\text { Error +/- } \\
(1 \sigma)\end{array}$ & $\begin{array}{c}\text { Calibrated Age } \\
\pm 2 \text { sigma }\end{array}$ & $\begin{array}{l}\Delta^{13} \mathrm{C} \% \\
\text { VPDB }\end{array}$ \\
\hline $\begin{array}{c}\text { GJP-01-14 } \\
1 \text { of } 2\end{array}$ & 16 & Plant Remains & 4.2 & 0.8 & 1125 & 30 & $960-1172$ & -23 \\
\hline $\begin{array}{c}\text { GJP-01-14 } \\
1 \text { of } 2\end{array}$ & 32 & Plant Remains & 9.1 & 0.8 & 1795 & 35 & $1619-1819$ & -22.4 \\
\hline $\begin{array}{c}\text { GJP-01-14 } \\
1 \text { of } 2\end{array}$ & 44.5 & Plant Remains & 4.4 & 0.8 & 2175 & 35 & $2066-2312$ & -20.5 \\
\hline $\begin{array}{c}\text { GJP-01-14 } \\
1 \text { of } 2\end{array}$ & 48.5 & Plant Remains & 7.8 & 0.7 & 2685 & 30 & $2753-2846$ & -24 \\
\hline $\begin{array}{c}\text { GJP-01-14 } \\
1 \text { of } 2\end{array}$ & 66 & Plant Remains & 11.6 & 1.02 & 3530 & 35 & $3702-3895$ & -22.8 \\
\hline $\begin{array}{c}\text { GJP-01-14 } \\
1 \text { of } 2\end{array}$ & 80.5 & Plant Remains & 2.2 & 0.5 & 4230 & 40 & $4628-4861$ & -24.1 \\
\hline $\begin{array}{c}\text { GJP-01-14 } \\
1 \text { of } 2\end{array}$ & 88 & Plant Remains & 6.9 & 0.5 & 5350 & 50 & $6002-6084$ & -24.4 \\
\hline $\begin{array}{l}\text { GJP-01-14 } \\
\text { 1of } 2\end{array}$ & 102 & Plant Remains & 8.7 & 0.6 & 5860 & 40 & $6563-6778$ & -27.7 \\
\hline $\begin{array}{l}\text { GJP-01-14 } \\
\text { 1of } 2\end{array}$ & 114 & Plant Remains & 6.2 & 1.01 & 6520 & 50 & $7323-7556$ & -22.4 \\
\hline $\begin{array}{c}\text { GJP-01-14 } \\
1 \text { of } 2\end{array}$ & 129 & Plant Remains & 14.2 & 1.35 & 7060 & 50 & $7789-7976$ & -25.5 \\
\hline $\begin{array}{l}\text { GJP-01-14 } \\
\text { 2of2 }\end{array}$ & 138.5 & Plant Remains & 3.9 & 0.51 & 7590 & 40 & $8343-8448$ & -26.8 \\
\hline $\begin{array}{l}\text { GJP-01-14 } \\
\text { 2of2 }\end{array}$ & 146.5 & Plant Remains & 3.6 & $\begin{array}{c}\text { Not } \\
\text { Reported }\end{array}$ & 8550 & 30 & $9494-9547$ & -26.1 \\
\hline $\begin{array}{l}\text { GJP-01-14 } \\
2 \text { of } 2\end{array}$ & 162.5 & Plant Remains & 2.9 & $\begin{array}{c}\text { Not } \\
\text { Reported }\end{array}$ & 9690 & 40 & $10827-11217$ & $\begin{array}{c}\text { Not } \\
\text { Reported }\end{array}$ \\
\hline
\end{tabular}




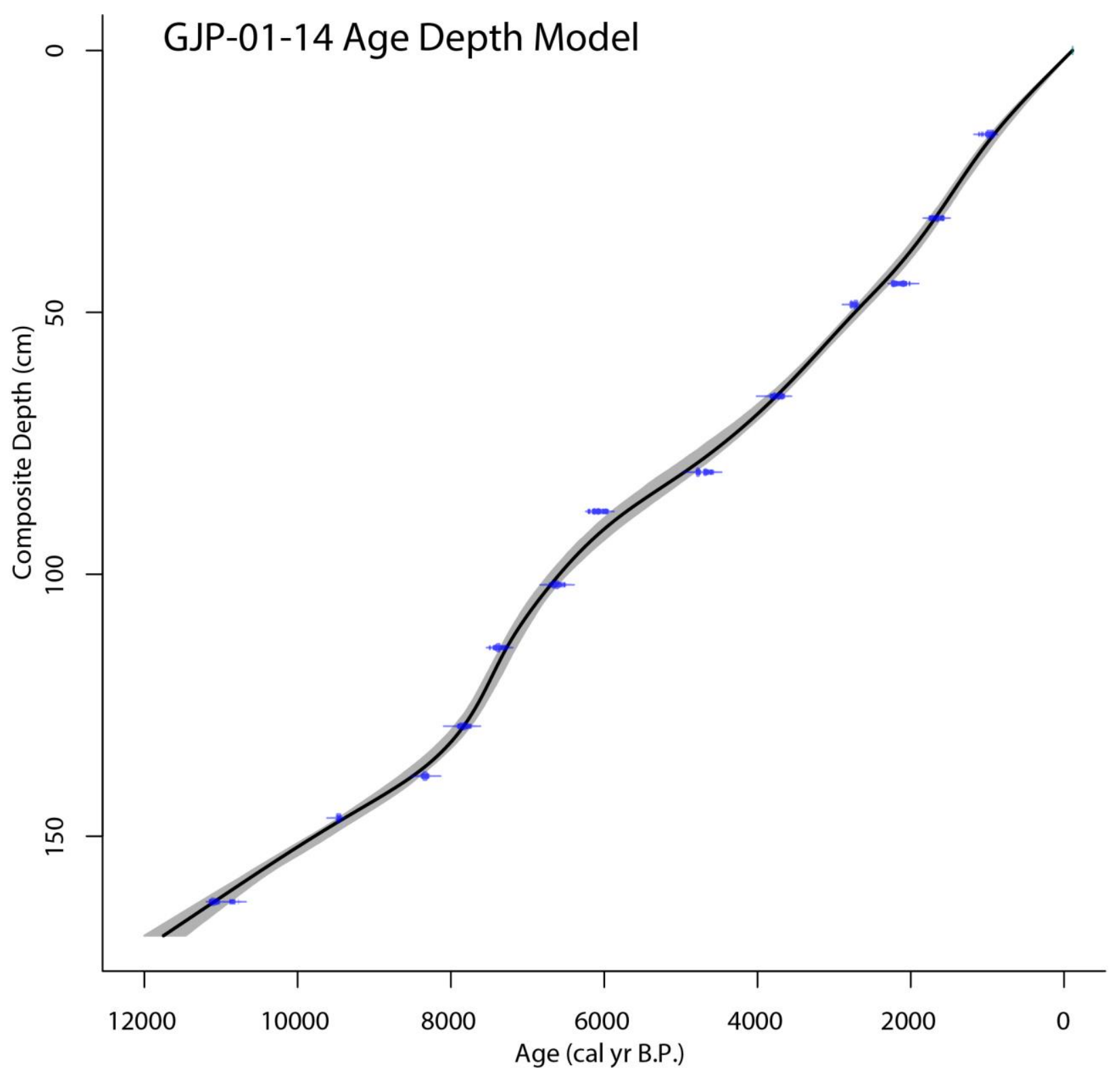

Figure 4: Age depth relationship for GJP-01-14 core created in using the Clam modeling package (Blaauw, 2010) for software R (v. 3.0.1; R Development Core Team, 2013) with 95\% confidence intervals for individual radiocarbon dates in blue.

\section{2) Multivariate Analysis}

Calculated correlation coefficients for each of XRF-based elemental abundance datasets reveal

that most of the geochemical elements are highly positively correlated with each other and negatively correlated with LOI (Table 3). The exception to this pattern is Ca, which is only weakly positively correlated with the other elements (but still negatively correlated with LOI). Principal component analysis yielded 2 components responsible for $91 \%$ of the observed variance in the dataset (Table 4). 
Most of the geochemical elements align with PC1, responsible for $80.6 \%$ of the variance (Table 3,

Figure 5). As suggested by their correlation coefficients, most of the geochemical elements are positively

264 correlated with PC1, while LOI is inversely correlated. Accordingly, the downcore scores for PC1 look

265 broadly similar to elemental counts from the Itrax (Figure 6). PC2 (10.7\% of variance) shows weak

266 correlations with most elements and LOI, but is highly positively correlated with the element Ca. We

267 recognize that $\mathrm{PC} 1$ is an extension of the elemental data and we utilize the principal component analysis

268 to highlight the similar behavior of these elements over the length of our record, and as justification for

269 interpreting each as a record of bedrock erosion (and therefore glacial activity). In the ensuing discussion,

270 we will consider Ti elemental abundances as a proxy for glacially derived sediment input to Gjøavatnet;

271 however, the use of PC1 or of a different element (apart from Ca, see below) would not change any of our

272 interpretations or conclusions.

273

274

Table 3: Correlation coefficients for variables used in PCA analysis

\begin{tabular}{|c|c|c|c|c|c|c|c|c|c|c|}
\hline $\begin{array}{c}\text { Correlation } \\
\text { Coefficients }\end{array}$ & $\mathbf{T i}$ & $\mathbf{A l}$ & $\mathbf{S i}$ & $\mathbf{K}$ & $\mathbf{C a}$ & $\mathbf{M n}$ & $\mathbf{F e}$ & $\mathbf{R b}$ & $\mathbf{S r}$ & $\mathbf{L O I}$ \\
\hline $\mathbf{T i}$ & 1.00 & & & & & & & & & \\
\hline $\mathbf{A l}$ & 0.81 & 1.00 & & & & & & & & \\
\hline $\mathbf{S i}$ & 0.87 & 0.75 & 1.00 & & & & & & & \\
\hline $\mathbf{K}$ & 0.97 & 0.81 & 0.95 & 1.00 & & & & & & \\
\hline $\mathbf{C a}$ & 0.78 & 0.61 & 0.50 & 0.66 & 1.00 & & & & & \\
\hline $\mathbf{M n}$ & 0.83 & 0.77 & 0.85 & 0.88 & 0.39 & 1.00 & & & & \\
\hline $\mathbf{F e}$ & 0.84 & 0.72 & 0.90 & 0.90 & 0.34 & 0.94 & 1.00 & & & \\
\hline $\mathbf{R b}$ & 0.95 & 0.71 & 0.88 & 0.95 & 0.69 & 0.77 & 0.83 & 1.00 & & \\
\hline $\mathbf{S r}$ & 0.91 & 0.69 & 0.82 & 0.90 & 0.80 & 0.65 & 0.68 & 0.94 & 1.00 & \\
\hline $\mathbf{L O I}$ & -0.91 & -0.67 & -0.69 & -0.82 & -0.85 & -0.63 & -0.64 & -0.86 & -0.85 & 1.00 \\
\hline
\end{tabular}

275

276

Table 4: Results from PCA analysis with 8 principal components

\begin{tabular}{|c|c|c|c|}
\hline $\begin{array}{c}\text { Principal } \\
\text { Component } \\
\#\end{array}$ & $\begin{array}{c}\text { Eigenvalue } \\
\text { of Cov (x) }\end{array}$ & $\begin{array}{c}\text { \% } \\
\text { Variance } \\
\text { Captured } \\
\text { this PC }\end{array}$ & $\begin{array}{c}\text { Cumulative } \\
\text { Variance } \\
\text { Captured }\end{array}$ \\
\hline $\mathbf{1}$ & 8.08 & 80.6 & 80.6 \\
\hline $\mathbf{2}$ & 1.08 & 10.72 & 91.32 \\
\hline $\mathbf{3}$ & 0.39 & 3.87 & 95.19 \\
\hline $\mathbf{4}$ & 0.21 & 2.09 & 97.28 \\
\hline $\mathbf{5}$ & 0.11 & 1.05 & 98.33 \\
\hline $\mathbf{6}$ & 0.08 & 0.84 & 99.17 \\
\hline
\end{tabular}


277

278

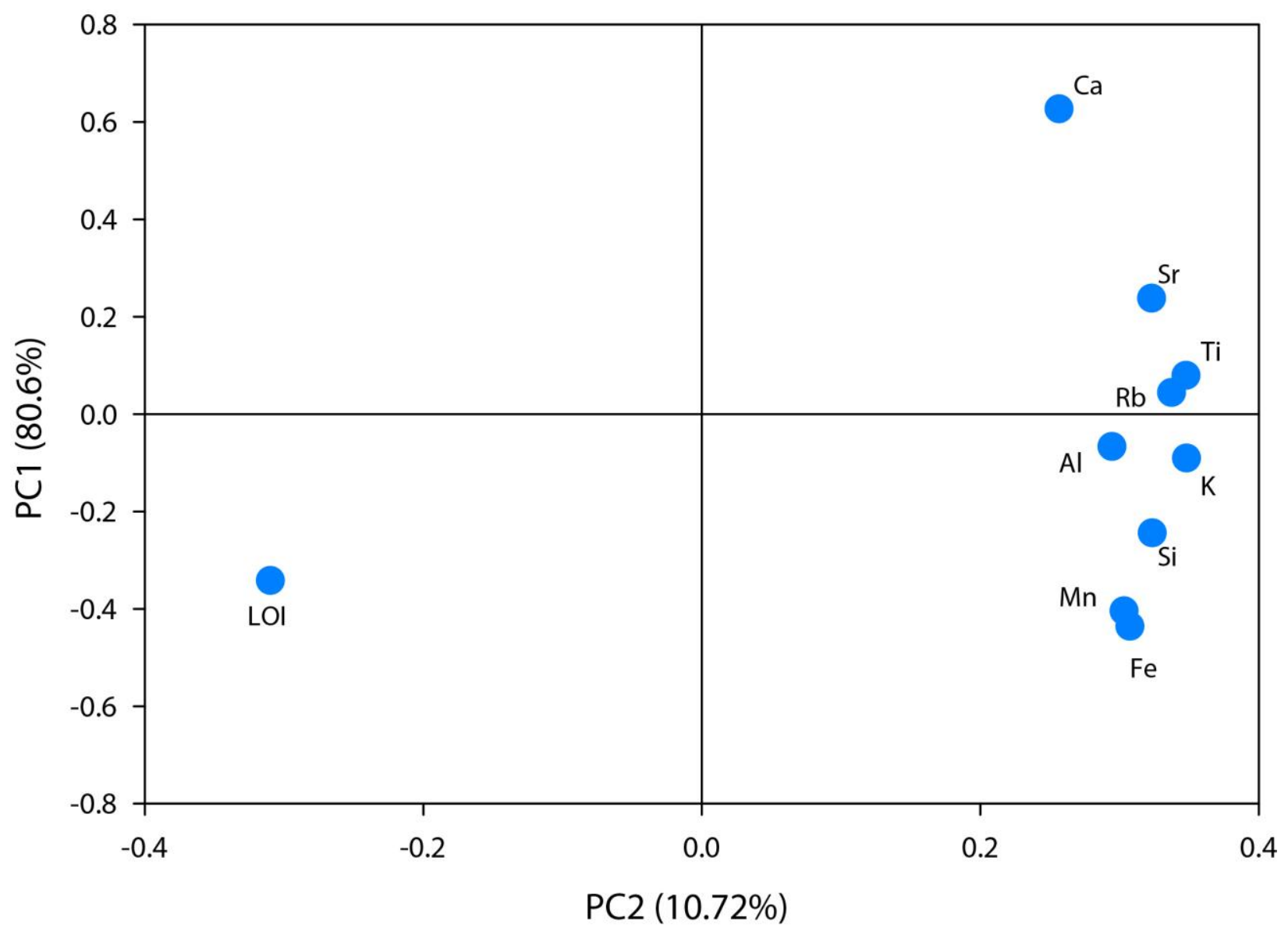

279

280

281

282

283

\begin{tabular}{|l|l|l|l|}
\hline $\mathbf{7}$ & 0.05 & 0.48 & 99.64 \\
\hline $\mathbf{8}$ & 0.02 & 0.19 & 99.83 \\
\hline
\end{tabular}

Figure 5: Ordination diagram showing $1^{\text {st }}(80.6 \%$ of variance $)$ and $2^{\text {nd }}(10.72 \%$ of variance $)$ principal components of PCA. 


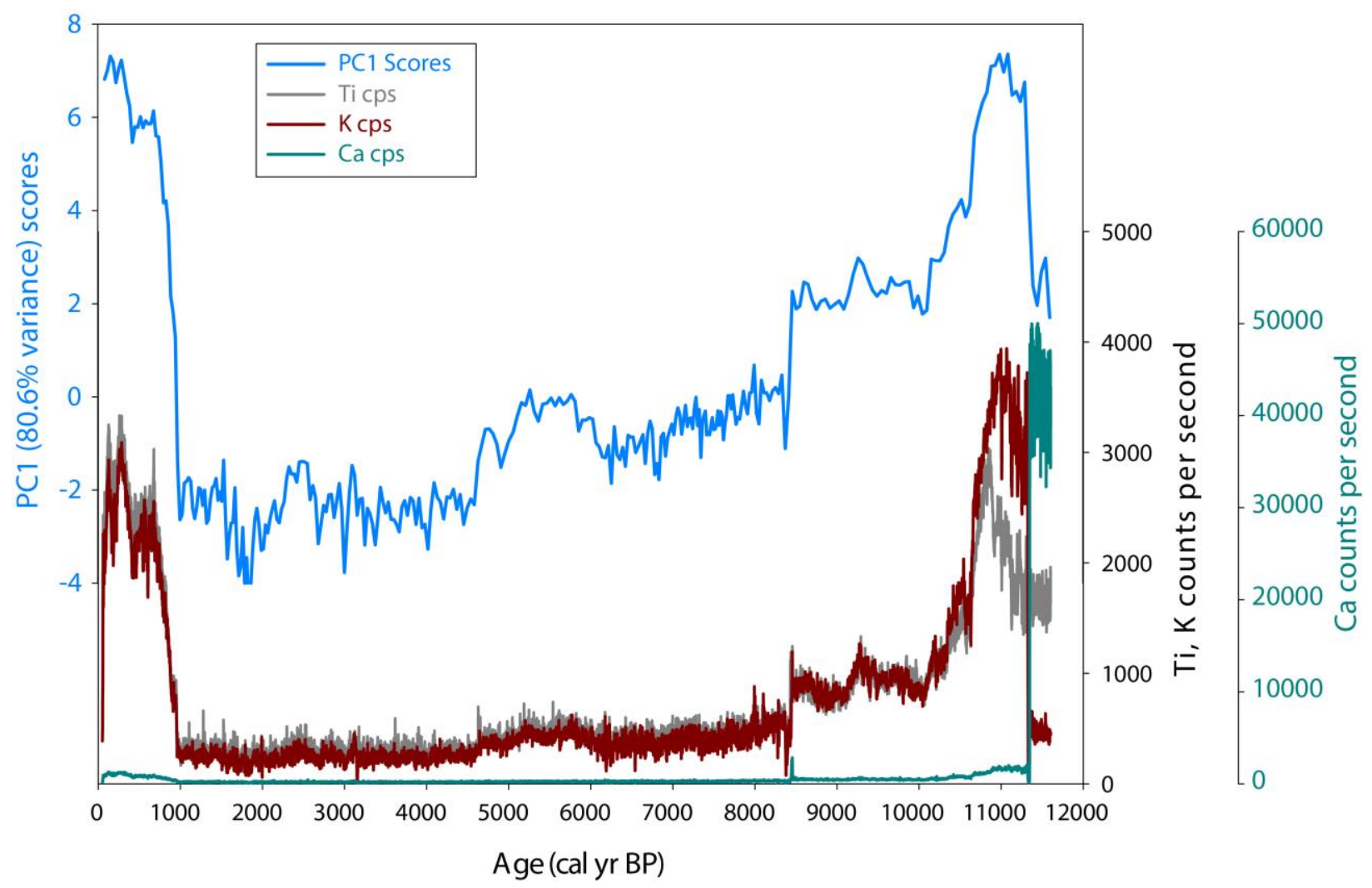

Figure 6: Downcore scores of $1^{\text {st }}$ principal component from PCA analysis (blue line) plotted on age scale with Itrax elemental data for Ti (gray), K (dark red) and Ca (cyan) for core GJP-01-14. Note different scale for $\mathrm{Ca}$ data relative to $\mathrm{Ti}$ and $\mathrm{K}$. 


\section{3) Stratigraphy and Interpretation of Stratigraphic Units}

The composite Gjøavatnet sedimentary sequence was separated into 4 major units: A, B, C, and $\mathrm{D}$, and Unit $\mathrm{C}$ was further divided into 3 distinct subunits (Figure 7). This determination was made based on major density transitions apparent in x-radiograph data and corresponding visual transitions between gray, silty sediment and brown, organic rich sediment (Figure 3). Proxy data (Itrax elemental data, diatom analyses, and LOI and DBD values) were then used to inform/confirm these definitions (Table 5)

307 (see below).

308 Table 5: Relevant proxy data for sedimentary units identified in Gjøavatnet record

\begin{tabular}{|c|c|c|c|c|c|c|c|c|}
\hline Unit & $\begin{array}{l}\text { Depth } \\
\text { Range } \\
(\mathbf{c m})\end{array}$ & $\begin{array}{c}\text { Approx. } \\
\text { Age } \\
\text { Range } \\
\text { (cal kyr } \\
\text { BP) }\end{array}$ & $\begin{array}{c}\text { Avg. Ca } \\
\text { cps }\end{array}$ & $\begin{array}{c}\text { Avg. Ti } \\
\text { cps }\end{array}$ & $\begin{array}{c}\text { Avg. } \\
\text { DBD } \\
\left(\mathrm{g} / \mathrm{cm}^{3}\right)\end{array}$ & $\begin{array}{l}\text { Avg. } \\
\text { LOI }\end{array}$ & $\begin{array}{c}\text { Avg. Acc. } \\
\text { Rate } \\
(\mathbf{c m} / \mathbf{k y r})\end{array}$ & $\begin{array}{l}\text { Avg. } \\
\delta^{13} \mathbf{C} \\
(\%)\end{array}$ \\
\hline Unit A & $\begin{array}{c}209.5- \\
162.5\end{array}$ & $\begin{array}{c}\text { Base - } \\
11.1\end{array}$ & $24466^{\dagger}$ & $1623^{\dagger}$ & $\begin{array}{l}0.71^{\dagger} \\
n=9\end{array}$ & $\begin{array}{c}3.9^{\dagger} \\
n=9\end{array}$ & 9.8 & $\begin{array}{l}-23.0 \\
n=5\end{array}$ \\
\hline Unit B & $\begin{array}{c}162.5 \\
- \\
136.5\end{array}$ & $\begin{array}{c}11.1- \\
8.4\end{array}$ & 655 & 1174 & $\begin{array}{c}0.22 \\
n=56\end{array}$ & $\begin{array}{c}13.0 \\
n=56\end{array}$ & 9.7 & $\begin{array}{c}-22.2 \\
n=13\end{array}$ \\
\hline Unit C & $\begin{array}{r}136.5 \\
-16.5 \\
\end{array}$ & $8.4-1.0$ & 231 & 372 & $\begin{array}{c}0.09 \\
n=198\end{array}$ & $\begin{array}{c}25.5 \\
n=198\end{array}$ & 18.4 & $\begin{array}{c}-27.1 \\
n=24\end{array}$ \\
\hline Unit C1 & $\begin{array}{c}89.5- \\
81\end{array}$ & $5.9-5.0$ & 253 & 489 & $\begin{array}{c}0.15 \\
n=18\end{array}$ & $\begin{array}{c}16.5 \\
n=18\end{array}$ & 10.1 & $\begin{array}{l}-27.3 \\
n=2\end{array}$ \\
\hline Unit C2 & $\begin{array}{c}48.5- \\
42\end{array}$ & $2.7-2.2$ & 199 & 341 & $\begin{array}{c}0.10 \\
n=14\end{array}$ & $\begin{array}{c}24.0 \\
n=14\end{array}$ & 15.7 & $\begin{array}{l}-27.6 \\
n=2\end{array}$ \\
\hline Unit C3 & $\begin{array}{c}32- \\
27\end{array}$ & $1.7-1.5$ & 174 & 279 & $\begin{array}{c}0.08 \\
n=11\end{array}$ & $\begin{array}{c}28.2 \\
n=11\end{array}$ & 21.6 & $\begin{array}{l}-28.5 \\
n=1\end{array}$ \\
\hline Unit D & $\begin{array}{c}16.5- \\
0\end{array}$ & $\begin{array}{c}1.0- \\
\text { present }\end{array}$ & 785 & 2157 & $\begin{array}{c}0.43 \\
n=29\end{array}$ & $\begin{array}{c}6.9 \\
n=29\end{array}$ & 15.7 & $\begin{array}{l}-27.7 \\
n=3\end{array}$ \\
\hline
\end{tabular}


a)

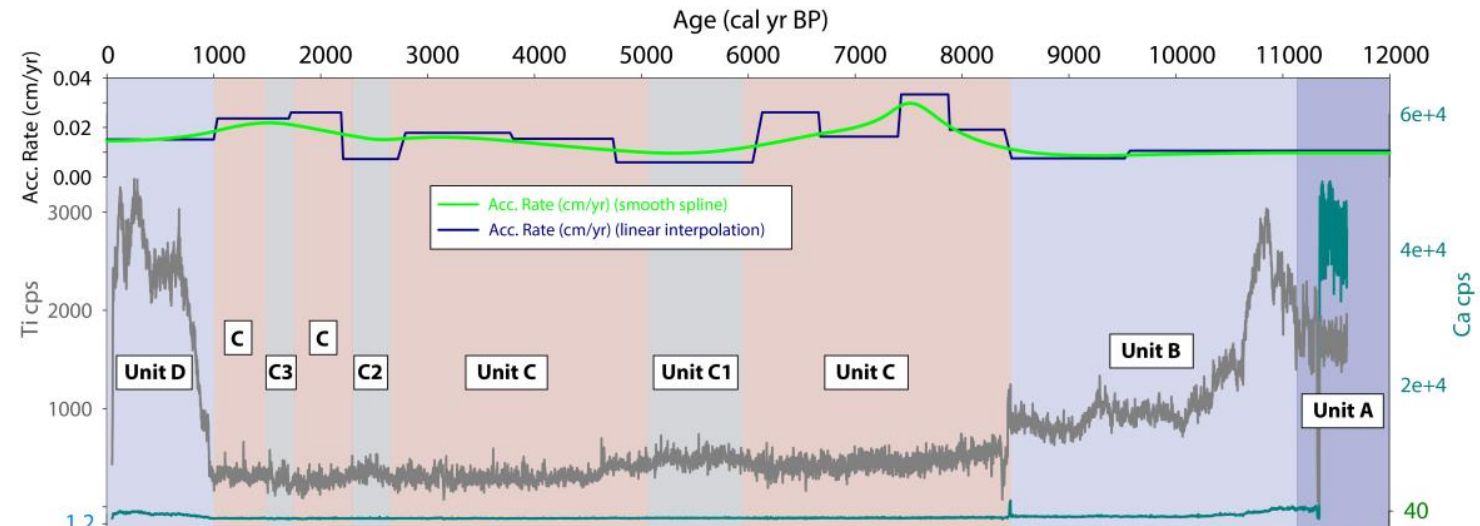

c)

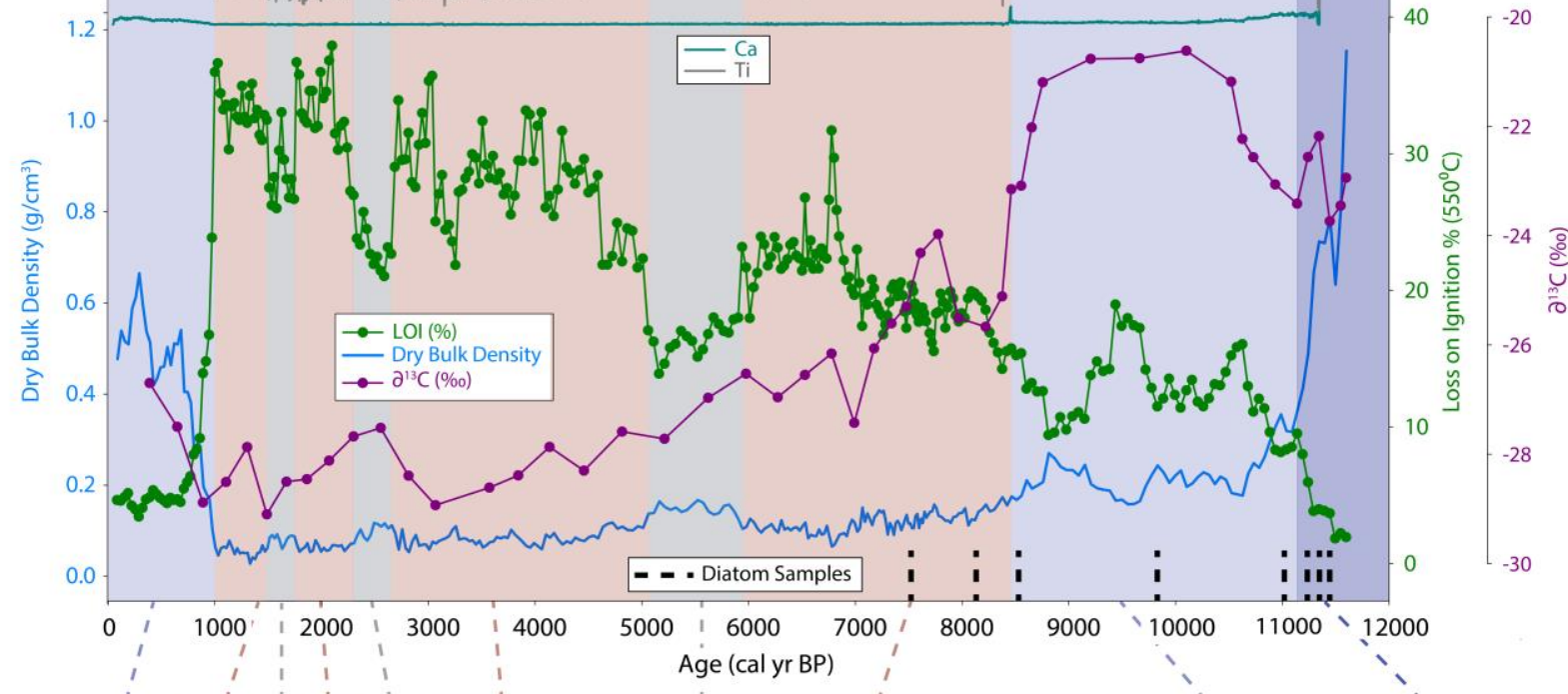

e)

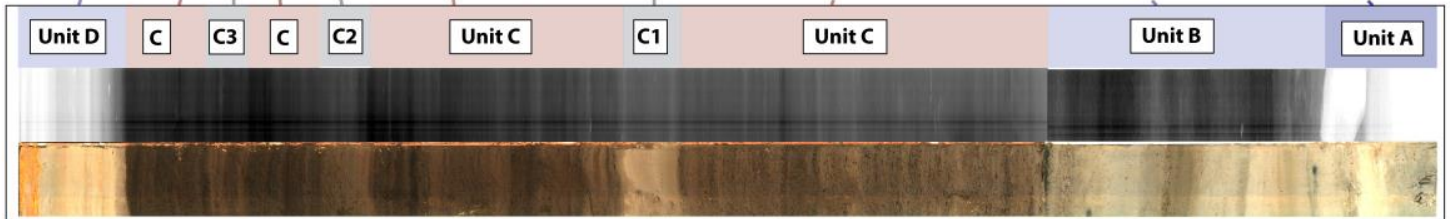


Unit A: Base of core $(206.5 \mathrm{~cm})-11.1 \mathrm{cal} \mathrm{kyr}$ BP $(162.5 \mathrm{~cm})$

\section{Glacial Till}

The basal sedimentary unit, Unit A, consists of dark to light gray diamict $(206.5 \mathrm{~cm}-\sim 170 \mathrm{~cm})$, which transitions to dense silty sand $(170-162.5 \mathrm{~cm})$. The diamict in the lower portion of this unit is massive and poorly sorted, with individual clasts up to $5 \mathrm{~cm}$ in diameter. The $\mathrm{x}$-radiograph of the upper section shows some faint evidence for horizontal bedding structures, but lacks the distinct laminations of later units. The unit broadly is characterized by low LOI values, ranging from $1.8 \%$ at $\sim 11.6 \mathrm{cal} \mathrm{kyr} \mathrm{BP}$ to $\sim 8 \%$ at 11.2 cal kyr BP with a mean value of 3.9\%. The highest dry bulk density values of the entire record are found in Unit A, with a mean value of $0.71 \mathrm{~g} / \mathrm{cm}^{3}$. Values decrease steadily from a maximum of $1.15 \mathrm{~g} / \mathrm{cm}^{3}$ at a depth of $167 \mathrm{~cm}$ (lowest sample) to $0.41 \mathrm{~g} / \mathrm{cm}^{3}$ at the top of the unit (Table 5, Figure 7). Unit $A$ has the $2^{\text {nd }}$ highest average Ti counts of the entire record $(1622 \mathrm{cps})$, with relatively little variation about the mean. Ca counts during the majority of this interval are the highest of any unit by nearly two orders of magnitude. They reach a maximum value of 50,014 cps and are above 30,000 cps for most of the unit (mean of 24,466 cps) (Table 5) before declining to $1500 \mathrm{cps}$ before the end of Unit A. $\delta^{13} \mathrm{C}$ values range from $-22.2 \%$ to $-23.7 \%$, with an average of $-23.1 \%$ o $(n=5)$. Diatom species were analyzed in 3 samples from Unit A (dashed lines in Figure 7). Assemblages were dominated by Pinnularia lenticular and Stauroneis anceps family (cf. gracilis, vandevijveri), which are characteristic of a silty, shallow freshwater environment (Perren et al., 2012; Wojtal et al., 2014) (Figure 8).

One of the most interesting aspects of Unit A is the high Ca abundance during in this interval. High Ca counts are also observed in the other piston core collected from Gjøavatnet (GJP-02-14), confirming that it is a persistent feature of the sediments across the lake basin. One possible interpretation of the calcium signal is that it represents a period when the lake basin was subject to marine influence. Diatom analysis, however, has revealed that all species present at the time were freshwater-dwelling, ruling out the possibility of a marine influence. We note here that despite the abundant driftwood on the narrow strip of land separating Gjøavatnet from the ocean today, we see no evidence in our proxy data to suggest sustained or meaningful marine influence on the lacustrine sediment record. 
We interpret the high $\mathrm{Ca}$ abundance as a signal of bedrock erosion from the marble units within the Gjøavatnet catchment. Although the majority of the underlying bedrock consists of banded gneiss of the Smeerenburgfjorden Complex (Hjelle and Ohta, 1974; Ohta et al., 2007).), there are two small outcrops of marble that would have resulted in glacial flour with elevated Ca content in the northwest part

354 of the catchment (blue outlines in Figure 1). The exposed marble units are not being eroded by the

355 Annabreen glacier today, but would have been subject to glacial erosion if the glacier advanced across the 356 outcrops. We suggest that the large decrease in XRF-inferred Ca deposition to the lake c. 11.5 cal kyr BP 357 represents the retreat of Annabreen up-valley from the marble outcrops. If this interpretation is correct, the abrupt decline in sedimentary $\mathrm{Ca}$ abundance $\sim 11.4$ cal kyr BP represents a threshold response as the glaciers retreated beyond the marble outcrops, and as such, we do not consider the large change in $\mathrm{Ca}$ abundance in our assignment of stratigraphic units.

The carbon isotopic signature of this section is also intriguing, suggesting at face value a variable but perhaps predominantly marine source (values ranging from -22.2 to -23.7\%o) (Meyers, 1997). Again, however, diatom analysis has ruled out this possibility. An alternative explanation may be found in the weathering of silicate rocks and limited recycling of carbon within the catchment immediately following deglaciation (Hammarlund, 1993). Glacial activity would have resulted in a large amount of freshly weathered siliciclastic material on the landscape following deglaciation. The weathering of this material could have resulted in bicarbonate delivery to the lake water, leading to ${ }^{13} \mathrm{C}$ enrichment (i.e. more positive $\delta^{13} \mathrm{C}$ values) of dissolved inorganic carbon and, therefore, of autochthonous organic material in the lake

369 (Hammarlund, 1993).

We interpret Unit A to represent a period when Annabreen was terminating at or near the coring

371 site during deglaciation of the catchment. Due to the extrapolated nature of our age model, we cannot 372 place a definitive date on the onset of sedimentation in Gjøavatnet. The highest dry DBD and lowest LOI 373 percentages are recorded during this interval, along with the presence of large individual clasts in the 374 sediment, all of which suggest substantial glacial presence proximal to the coring site. The lowermost $375 \sim 30 \mathrm{~cm}$ of GJP-01-14 is comprised of glacial till/diamict, which was likely deposited when the glacier was 
376 directly adjacent to (or overriding) the coring site. We speculate that the remainder of Unit A ( 167-

$377 \quad 162.5 \mathrm{~cm}$ ), when DBD values were still relatively high, represents a period when Annabreen was likely

378 terminating within the lake.

379 The boundary between Unit A and Unit B at $\sim 11.1$ cal kyr BP is primarily defined by DBD

380 values, a shift in diatom species, and a major density change seen in the x-radiograph data (Figure 3).

381 The diatom samples below the transition represent a silt-dominated environment (e.g Perren et al., 2012),

382 as would be expected if Annabreen was terminating within the lake or was contributing a significant

383 amount of meltwater to the lake system, whereas the samples above (in Unit B) are more diverse and

384 point to a reduction of suspended silt in the water column. Together, these proxies suggest that while

385 Annabreen was still active during the deposition of Unit B (see below), it was reduced in size and/or 386 influence compared to Unit A. 


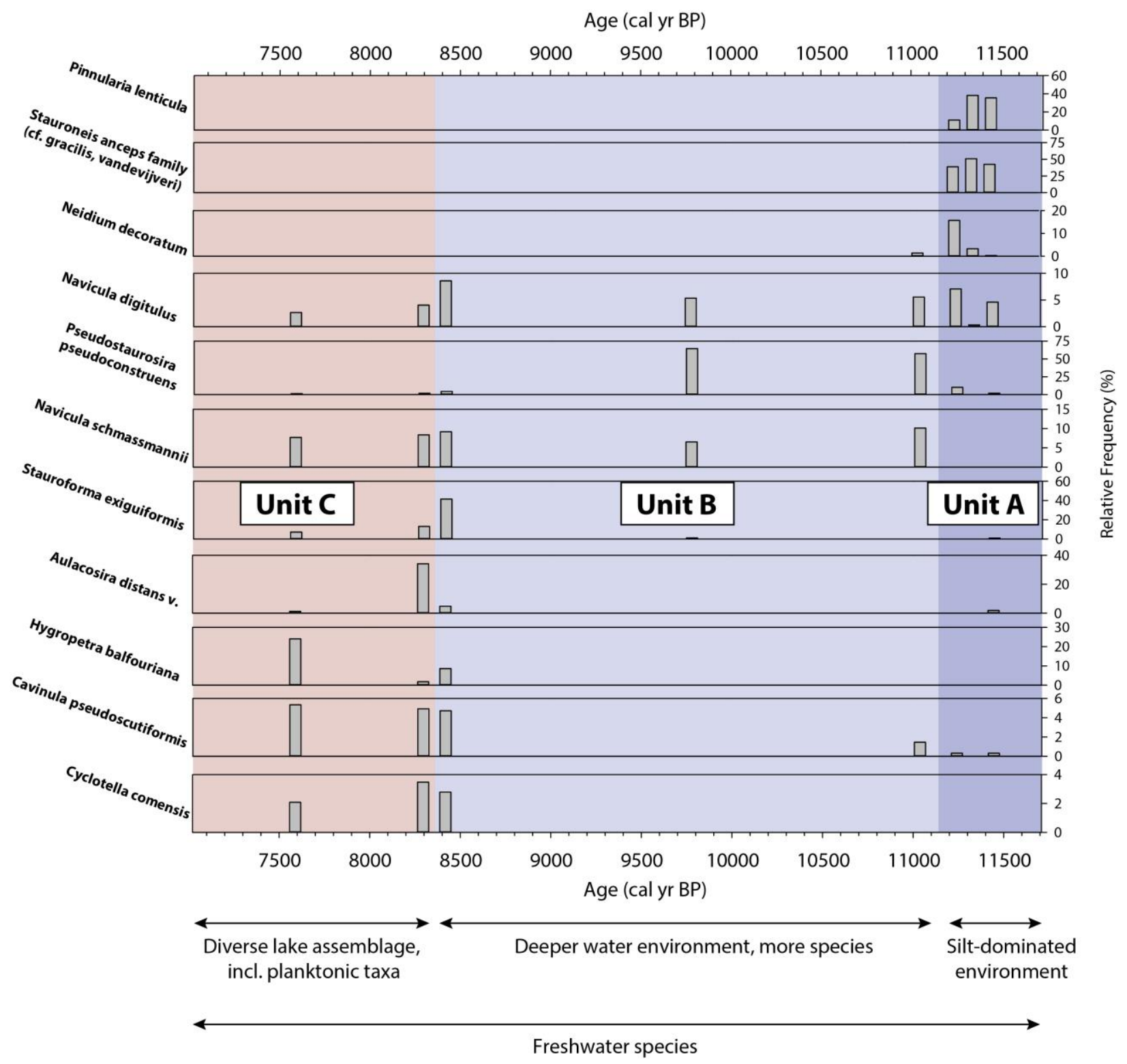

Figure 8: Percent abundance of diatom taxa throughout the early evolutionary history of Gjøavatnet. Note sedimentary unit delineations (labels and background shaded colors) that correspond with Figure 7.

\section{Unit B: 11.1cal kyr BP $(162.5 \mathrm{~cm})-8.4 \mathrm{cal} \mathrm{kyr}$ BP $(136.5 \mathrm{~cm})$}

\section{Deglaciation of Gjøavatnet Catchment}

Unit B consists of a mixture of gray, laminated, clayey silt interbedded with relatively organic rich brown material. It is characterized by generally low but variable LOI values ranging from $8.1-19 \%$

396 (mean of 13.0\%) (Figure 7). DBD values $\left(0.14-0.36 \mathrm{~g} / \mathrm{cm}^{3}\right.$; mean of $0.22 \mathrm{~g} / \mathrm{cm}^{3}$ ) are relatively high

397 during this unit, though much lower than in preceding Unit A. Ti counts are higher in the lower portion of 
this unit than Unit A, increasing to a maximum of 3034 counts at $~ 10.8$ cal kyr BP before decreasing to $\sim 800-1,000 \mathrm{cps}$ for the majority of the Unit B. Ca counts in Unit B are significantly lower than in Unit A, 400 decreasing from $\sim 1,500$ counts at the base of Unit B to $\sim 300 \mathrm{cps}$ (average value of $655 \mathrm{cps}$ ). $\delta^{13} \mathrm{C}$ values 401 are the most enriched in this section of the core, rising from $\sim-23.5 \%$ at $162.5 \mathrm{~cm}$ to a value of $\sim-21 \%$ o 402 (average of $-22.2 \%, n=13$ ).

Three samples from Unit B were analyzed for diatom taxonomy. Assemblages in the lowermost

404 two samples are dominated by Navicula (Genkalia) digitulus and Pseudostaurosira pseudoconstruens and 405 also contain the first appearance of Navicula schmassmannii in the sediment record (Figure 8). These 406 species are characteristic of a deeper lake with less suspended silt than the species from Unit A (Perren et al., 2012). The third sample, taken at a depth of $137 \mathrm{~cm}$ (approx. $8.6 \mathrm{cal} \mathrm{kyr} \mathrm{BP),} \mathrm{is} \mathrm{characterized} \mathrm{by} \mathrm{a}$ more diverse assemblage including Stauroforma exiguiformis, Hyropetra balfouriana, and Aulacoseira distans.

We interpret Unit B to represent an interval when Annabreen was still present within the 411 catchment, but likely not terminating within the lake. The two oldest diatom samples from this interval 412 ( 11 and $9.7 \mathrm{cal} \mathrm{kyr} \mathrm{BP)} \mathrm{(Figure} \mathrm{7,} \mathrm{Figure} \mathrm{8)} \mathrm{are} \mathrm{characteristic} \mathrm{of} \mathrm{a} \mathrm{deeper} \mathrm{lake} \mathrm{with} \mathrm{lesser} \mathrm{suspended}$ 413 silt load than during the deposition of Unit A. Elemental abundance data (Figures 6, 7) suggest a broad 414 decrease in the influence of Annabreen on the sediment record across this interval, although reductions in 415 elemental counts occur stepwise (cf., Ti counts). The LOI trend across Unit B is also non-linear and is 416 quite variable at multi-centennial timescales (Figure 7), suggesting the glacier may have been fluctuating 417 dynamically during this time and/or that sedimentation was influenced by glaciofluvial dynamics in the 418 glacier forefield as ice retreated. The third diatom sample from this section (just prior to 8.4 cal kyr BP) 419 (Figure 8) reveals a more diverse assemblage than the two older samples from Unit B, including 420 planktonic taxa. Again, this assemblage suggests Annabreen's influence on sedimentation in the lake 421 waned throughout this period.

422 Bulk organic carbon isotope values in Unit B are the most positive of the record, with a mean of $42322.2 \%$. Such a value is generally associated with marine algae (Meyers, 1997), however, only freshwater 
diatom species are found in the Gjøavatnet sediment record, precluding a marine source for the relatively

${ }^{13} \mathrm{C}$-enriched carbon isotope values. As discussed above, a possible explanation is the weathering of glacial flour derived from silicate rocks during this time that could have increased the $\delta^{13} \mathrm{C}$ value of DIC (dissolved inorganic carbon) in Gjøavatnet (Hammarlund, 1993).

The boundary between Unit B and Unit C at $~ 8.4$ cal kyr BP is marked by an increase in LOI, an abrupt decrease in Ti abundance, and a concomitant shift in $\delta^{13} \mathrm{C}$ values (Figures 6, 7, 8). It is apparent that the nature of sedimentation in Gjøavatnet changed dramatically at this point. The most likely explanation is the disappearance, or the dramatic reduction in size, of the Annabreen glacier at $\sim 8.4$ cal kyr BP.

\section{Unit C: 8.4 cal kyr BP $(136.5 \mathrm{~cm})-1.0 \mathrm{cal} \mathrm{kyr}$ BP $(16.5 \mathrm{~cm})$}

Unit C comprises the majority of the sediment record from Gjøavatnet (120 cm of $\sim 206$ total) and is composed of laminated brown organic rich sediment with interbedded gray minerogenic layers. The highest LOI values of the entire core are recorded in Unit C, and generally follow a linear increasing trend from $\sim 18 \%$ to $35 \%$ (average of $25.5 \%$ ) (Figure 7). This linear trend is interrupted by at least three distinct

440 multicentennial-scale intervals characterized by abrupt shifts to relatively lower LOI values, higher Ti and 441 DBD values, and decreases in sedimentation rate. These subunits are defined as $\mathrm{C} 1(81-89.5 \mathrm{~cm}, \sim 5.0-$ 4425.9 cal kyr BP); C2 (42-48.5cm, 2.2 - 2.7 cal kyr BP); and C3 (27-32cm, 1.5-1.7 cal kyr BP). Proxy data 443 for these three subunits are compared to average values from the remainder of Unit $\mathrm{C}$, and presented in 444 Table 5, to examine the differences between these subunits and Unit $\mathrm{C}$ in general. DBD values for Unit C 445 generally follow the inverse trend of LOI, beginning at $\sim 0.15 \mathrm{~g} / \mathrm{cm}^{3}$ and declining to a minimum of 0.03 $446 \mathrm{~g} / \mathrm{cm}^{3}$ near the top of the section. Ti counts are generally low throughout this portion of the record, 447 ranging from $88-661 \mathrm{cps}$ with an average value of $372 \mathrm{cps}$. Ca counts are extremely low in Unit C, 448 averaging 231 counts (max of $305 \mathrm{cps}$, min of $69 \mathrm{cps}$ ), with little variation. During the deposition of this 
sedimentary unit we interpret $\mathrm{Ti}$ abundances to reflect catchment dynamics unrelated to glacier activity (e.g., such as changes in runoff), or by changes in dilution by organic matter deposition. steadily decreased to $-28.5 \%$ (average value of $-27.1 \%$ ). Two samples analyzed for diatoms from the base of this unit, at $~ 8.1$ (135.5 cm depth) and $7.6 \mathrm{cal}$ kyr BP $(121.5 \mathrm{~cm}$ depth $)$, show similar assemblages to the uppermost sample from Unit B (Figure 8), revealing a diverse community including planktonic diatoms living in the upper water column completely melted or was too small to influence sedimentation in the lake. Ti counts and DBD are at their lowest during this period (Table 5, Figure 7). Bulk $\delta^{13} \mathrm{C}$ values during this period average $-27.1 \%$, likely reflecting a lacustrine algal source (-25 to $-30 \%$ ) (Meyers, 1997). LOI values increase from $\sim 20 \%$ at $\sim 8.0$ cal kyr BP to nearly $40 \%$ near the transition to Unit D at $1.0 \mathrm{cal} \mathrm{kyr}$ BP. An increasing trend in $\%$ organic matter during the Holocene has also been observed in other Svalbard lakes (e.g. Gjerde et al., in press; van der Bilt et al., 2015) and is attributed to lake and catchment ontogeny and greater nutrient recycling. The trend may have also have been influenced by increasing preservation of organic matter, as declining summer insolation potentially shortened the ice-free season resulting in greater bottom water anoxia or hypoxia (Laskar et al., 2004).

\section{Interpretation of Subunits C1, C2, and C3}

Unit $\mathrm{C}$ is punctuated by abrupt transitions between brown, organic-rich sediment and gray, more minerogenic sediments (the latter defined as subunits C1-C3; Figure 7). These transitions are apparent in LOI, visual stratigraphy, x-radiograph images, and DBD values. As evidenced by the visual stratigraphy,

471 core images, and x-radiograph, these units appear massive, with few laminations. Subunits C1-C3 could

472 represent: (i) short-lived advances of the Annabreen glacier, (ii) slump activity (e.g. turbidites), or (iii)

473 periods of reduced organic matter accumulation. We suggest that advances of Annabreen are not likely to 474 have caused these changes because sediment characteristics during subunits $\mathrm{C} 1, \mathrm{C} 2$, and $\mathrm{C} 3$ are not 
consistent with other intervals associated with glacial erosion in the catchment (Units A, B, D). Ti counts

476 are much lower in the Unit C subunits, for example (Figure 7). Additionally, the relationship between Ti

477 and \%LOI is broadly similar across Unit C and subunits C1-C3 relative to Units A, B and D, inferred to

478 represent a glacial signature (Figure 9). Furthermore, the timing of Unit C1 corresponds with the interval

479 when nearby lake Hakluytvatnet completely dried out, likely in response to dry conditions (c. 7.7-5.0 cal

480 kyr BP), suggesting the precipitation regime was not favorable for the regrowth of Annabreen (Gjerde et

481 al., in press; Balascio et al., in press). It is also unlikely that these subunits were the result of slump

482 events. Radiocarbon dates from either side of both units C1 and C2 were used to quantify sedimentation

483 rates across each interval using a linear interpolation between data points (Figure 7), and indicate that

484 sedimentation rates slowed during deposition of these subunits. Mass wasting events, such as slumping,

485 would lead to an increase, not a decrease in sedimentation rate.

486 We therefore interpret subunits $\mathrm{C} 1, \mathrm{C} 2$, and $\mathrm{C} 3$ as intervals of reduced organic productivity, most

487 likely driven by periods of prolonged summer lake ice cover and/or drier and colder conditions on

488 Amsterdamøya. Sediment was likely delivered to the lake during a short period of reduced ice cover

489 during the summer, which have been potentially limited to a moat around the lake edge. 


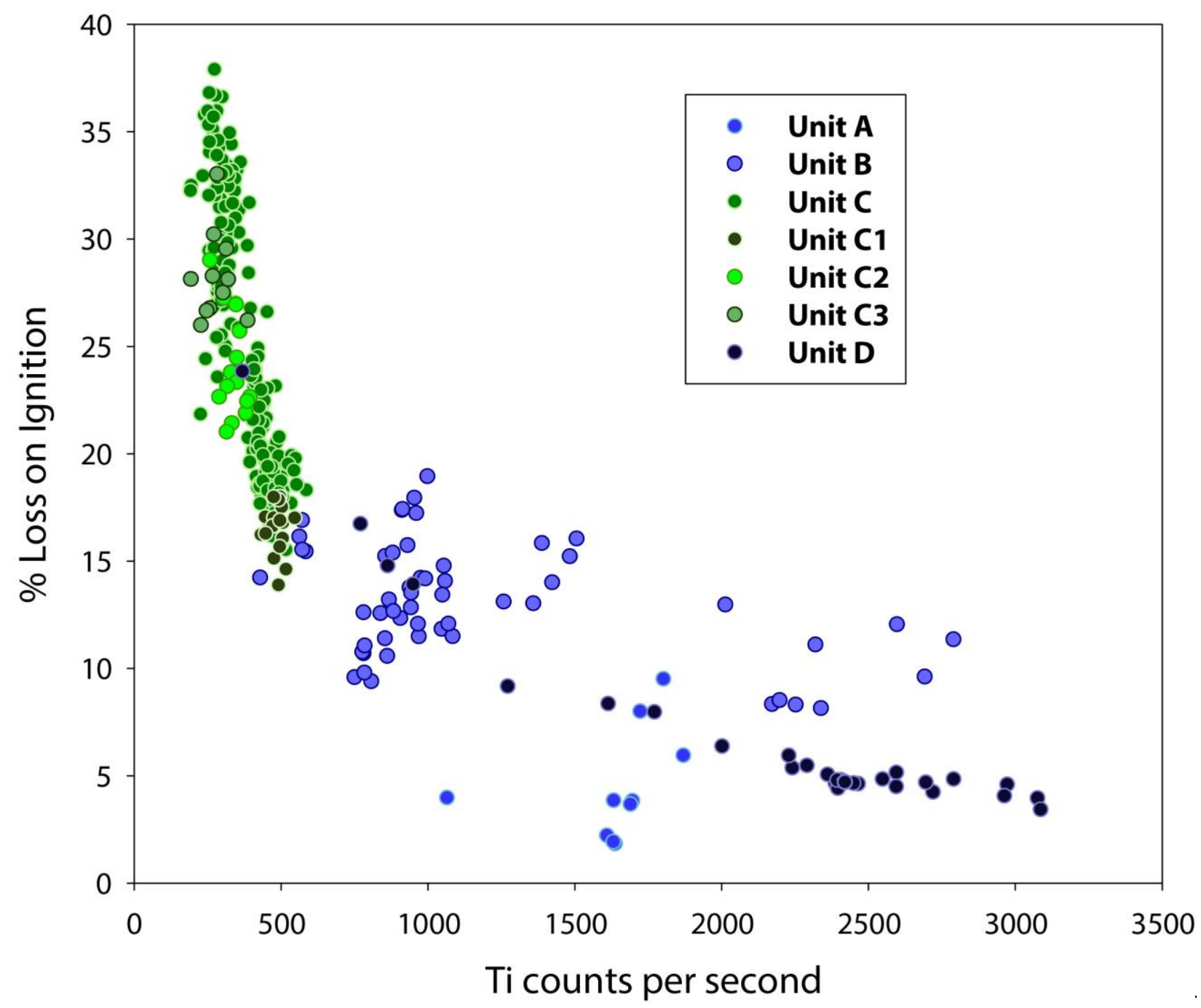

491 Figure 9: Relationship between \% Loss-on-ignition (LOI) and Ti counts from Itrax. Data from 492 sedimentary units when Annabreen glacier is interpreted to be present are shown in blue shades (Unit A, 493 B, D); data from units when Annabreen interpreted to be absent are shown in green shades (Unit C, C1,

Unit D: 1.0 cal kyr BP $(16.5 \mathrm{~cm})$ - present

Re-advance of Annabreen

The uppermost stratigraphic unit, Unit D, is characterized by an abrupt shift to gray, minerogenic sediment with faint laminations and a small number of sand sized grains (visually identified from the split 
core). Unit D is characterized by low LOI values (mean of $6.9 \%$ ) and high DBD (mean of $0.43 \mathrm{~g} / \mathrm{cm}^{3}$ )

504 (Table 5). The dense nature of Unit D is also evident from the X-radiograph (Figure 7). Ca counts increase in this unit relative to Unit B (average of 785 vs. 231), but remain nearly two orders of magnitude lower than Unit $\mathrm{A}$ at the base of the core. Bulk $\delta^{13} \mathrm{C}$ values increase from $-28.9 \%$ to $-26.7 \%$ o across the three samples representing this section. Ti counts in Unit D are the highest of the entire record 508 (mean of 2,127 cps).

We interpret Unit D to represent the reemergence of the Annabreen glacier, though this could also represent the transition from residual cold-based ice to a polythermal glacier. The youngest radiocarbon date from the Gjøavatnet record was taken just below this transition, allowing confident age assignment to

512 the boundary. Although there are only three $\delta^{13} \mathrm{C}$ samples from this interval, we note that they increase

513 from $-28.9 \%$ to $-26.7 \%$, a change similar in magnitude to the pattern seen at the beginning of Unit B, 514 which is likely related to increased glacial erosion and delivery of relatively ${ }^{13} \mathrm{C}$-enriched material to the 515 lake (Hammarlund et al., 1993).

\section{Summary}

The sedimentary units described here represent the broad phases of environmental change within the Gjøavatnet catchment. Unit A represents the period when Annabreen was likely larger than today and much of the catchment covered by ice. We infer that the glacier was terminating within the lake during this time. The transition to Unit B at $\sim 11.1$ cal kyr BP likely marks the time when Annabreen retreated

521 from the lake basin. We propose that the glacier was present in the Gjøavatnet catchment until $\sim 8.4 \mathrm{cal}$

522 kyr BP. From 8.4-1.0 cal kyr BP the glacier was absent or had become dramatically diminished in size,

523 and variations in sediment properties were likely controlled primarily by changes in summer temperature

524 and/or the duration of the summer ice free season. At $\sim 1$ cal kyr BP the local ELA lowered enough to 525 allow Annabreen to reform, and the glacier has been terminating in the lake since that time.

\section{5) Regional Paleoclimate Context of Gjøavatnet Record}

\section{1) Early Holocene: Deglaciation of Amsterdamøya}


During the Last Glacial Maximum, ice extended all the way to the shelf edge in NW Svalbard, $~ 8$ $\mathrm{km}$ offshore (Ingólfsson and Landvik, 2013). During this time it is likely that the majority of the Gjøavatnet catchment was covered by ice, although the $>300 \mathrm{~m}$ high plateaus on the island have been ice free for at least $80 \mathrm{cal} \mathrm{kyr} \mathrm{BP} \mathrm{(Landvik} \mathrm{et} \mathrm{al.,} \mathrm{2003).} \mathrm{Ice} \mathrm{began} \mathrm{to} \mathrm{retreat} \mathrm{from} \mathrm{the} \mathrm{shelf} \mathrm{edge} \mathrm{sometime}$ prior to 14 cal kyr BP, reaching the coast of NW Svalbard by 13.8 cal kyr BP (Ingólfsson and Landvik, 2013). The deglaciation of the nearby Hakluytvatnet catchment at $~ 12.8$ cal kyr BP suggests some small cirques on the island were largely ice-free by this time (Gjerde et al., in press). However, Annabreen was still terminating near the coring site in Gjøavatnet for another $\sim 1.7 \mathrm{kyr}$ until it retreated out of the lake basin at $\sim 11.1$ cal kyr BP and then disappeared, or at least greatly diminished in size, at 8.4 cal kyr BP. Proglacial lake records from the nearby Mitrahalvøya peninsula also point to a complex deglacial history in western Svalbard, with the catchment of Lake Kløsa deglaciating 9.2 cal kyr BP (Røthe et al., 2015), while glacial ice persisted in the catchment of Lake Hajeren until 7.4-6.7 cal kyr BP (van der Bilt et al., 2015) (Figure 10). Further south in the Linné valley, the Linnébreen glacier and another small cirque glacier in the same area are believed to have melted away during the early Holocene ( Svendsen and Mangerud, 1997; Snyder et al., 2000; Reusche et al., 2014). Lacustrine alkenone-based temperature reconstructions from Amsterdamøya and the Mitrahalvoya peninsula also point to warm conditions before $\sim 8$ kyr BP (van der Bilt et al., 2016).

The proposed final deglaciation of the Gjøavatnet catchment ( 8.4 cal kyr BP) occurred during a prolonged period of warm surface water conditions in Fram Strait (Müller et al., 2012; Werner et al., 2013; 2015; Rasmussen et al., 2014). Aagaard-Sorensen et al. (2014) found the warmest Mg/Ca based temperatures in their record from core MSM5/5-712-2 from 10.5-7.9 kyr BP. $\mathrm{IP}_{25}$ concentrations (a biomarker indicative of diatoms associated with sea ice) (Belt et al., 2007) from the same core also suggest the region experienced "significantly reduced ice cover" between 8.2 and 7.8 cal kyr BP (Müller et al., 2012). $\mathrm{IP}_{25}$ concentrations in the nearby MSM5/5-723-2 core also suggested warm temperatures and low concentrations of sea ice from the period $\sim 11-7 \mathrm{kyr}$ BP (Werner et al., 2015). Foram-based 
557 temperatures also suggest increased advection of warm Atlantic water into this part of the Fram Strait

558 during this time (Werner et al., 2013). While we acknowledge the possibility that Annabreen was

559 dramatically reduced in size during the mid-Holocene (or became a cold-based glacier with little erosive

560 power), we point to warming trends seen in marine records, along with evidence that many other glaciers

561 in Svalbard melted away during this time (Figure 10), as strong evidence for our interpretations.

562 Warmer conditions following deglaciation generally define the early Holocene climate of this

563 region, although periodic cooling events have been identified in the North Atlantic and attributed to

564 freshwater forcing (Sejrup et al., 2016). The "8.2" event (Alley et al., 1997) is the most prominent of

565 these, although we do not see it expressed in the Gjøavatnet record, a finding that echoes another similar

566 study from Svalbard (van der Bilt et al., 2015). It may be that dry conditions during this time (Rohling

567 and Pälike, 2005), coupled with its brief duration (Thomas et al., 2007), prevented Annabreen from re-

568 growing sufficiently to impact the sediment in Gjøavatnet.

569 
b)

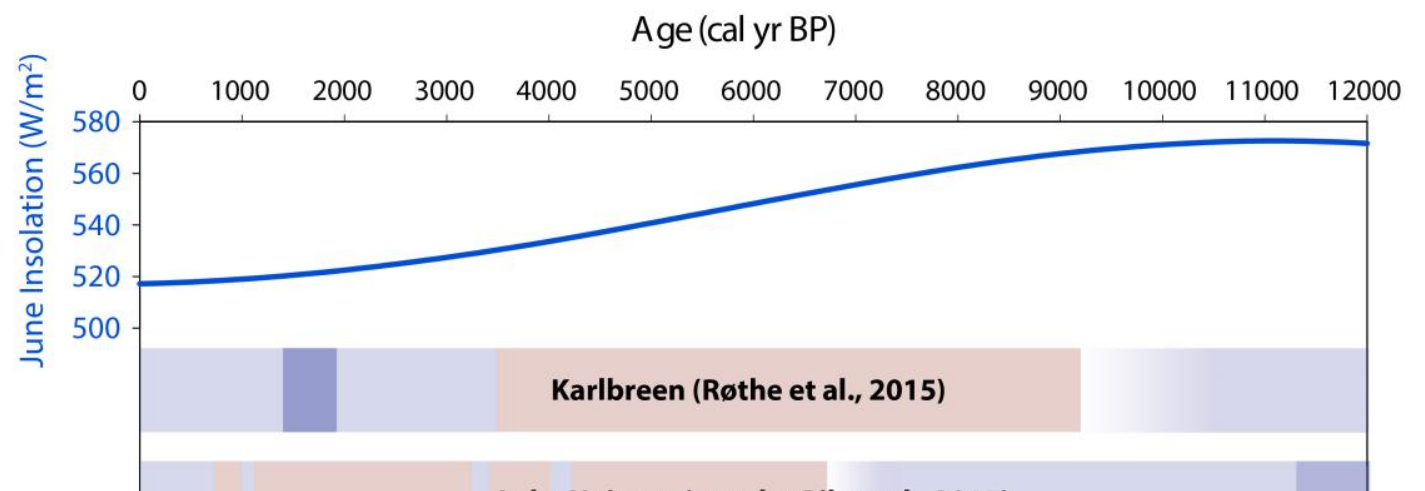

c)

d)

Longyearbreen (Humlum et al., 2005)

e)

Linnebreen (Svendsen and Mangerud, 1997) ?

f)

Linnedalen W. Cirque (Snyder et al., 2000)

Figure 10: Holocene glacial activity reconstructions from Svalbard: a) June insolation values at $79^{\circ} \mathrm{N}$ over the Holocene (Laskar et al., 2004); schematic depiction of glacier activity in Svalbard based on published reconstructions: a) and b) proglacial lake reconstructions from Mitrahalvøya peninsula (Røthe et al., 2015; van der Bilt et al., 2015); c) proglacial paleosol and vegetation study (Humlum et al., 2005); d) \& e) proglacial lake records from Linnévatnet (Svendsen and Mangerud, 1997; Snyder et al., 2000); f) $\%$ LOI and titanium counts from Gjøavatnet (this study). Blue boxes represent periods of glacial activity (dark blue $=$ enhanced glacial activity), red boxes suggest no glacier was present in the catchment or glacial activity was greatly reduced; gray boxes indicate periods of reduced organic matter accumulation (Gjøavatnet) or increased laminations (Snyder et al., 2000) that are not interpreted as glacial activity.

\section{2) Middle Holocene - Sea ice and freshwater influences on Amsterdamøya climate}


Annabreen was absent from the catchment. This period is generally marked by the absence of a glacier in the Gjøavatnet catchment and punctuated by periodic decreases in organic matter accumulation in the lake

587 (subunits C1-C3). We hypothesize that the most likely mechanism for these intervals is an abrupt change

588 in temperature and/or precipitation (we note these two parameters are positively correlated today (Førland 589 et al., 2011)), which at this maritime location would most likely be driven by offshore oceanographic 590 conditions. Periodic increases in freshwater input and the presence of a surface freshwater layer (and 591 likely accompanying sea ice) could dramatically lower both temperature and precipitation near 592 Gjøavatnet, leading to the reduction in organic matter accumulation seen during the subunits. 593 Interestingly, Unit C1 occurs during a period of increased deposition of discrete laminae in Linnévatnet 594 (Snyder et al., 2000) (grey shaded area in Figure 10). The deposition of Unit C1 also occurs during a 595 hiatus in sedimentation in nearby Haklutuyvatnet (Gjerde et al., in press), suggesting dry conditions on 596 Amsterdamøya during this time. Numerous authors have suggested the presence of a freshwater cap or 597 lens near Svalbard (Rasmussen et al., 2013; Werner et al., 2015, 2013), although the exact timing and 598 magnitude of this oceanographic feature remains somewhat ambiguous. With respect to the most 599 prominent of the subunits, $\mathrm{C} 1$, there does appear to be complimentary evidence for oceanographic 600 changes during the period $\sim 6-5$ cal kyr BP.

601 Multiple marine records from near Svalbard and in the Fram Strait have found evidence for an 602 increased flux of cold water from the Arctic around 6 cal kyr BP. Ślubowska et al. $(2005,2007)$ found 603 increases in the concentrations of the benthic foraminifera E. excavatum, characteristic of Arctic ocean 604 water, $\sim 6.8$ and 6 cal kyr BP north of Svalbard. Ebbesen et al. (2007) cite a shift in $\delta^{18} \mathrm{O}$ values of 605 foraminiferal tests at $6 \mathrm{cal} \mathrm{kyr} \mathrm{BP}$ as evidence for a change in the relative contributions of water masses 606 off western Svalbard. Numerous studies have also shown that the thermophilious mollusk, Mytulis edulis, 607 likely died out in northern Svalbard around 6-5 cal kyr BP (Blake, 2006; Salvigsen, 2002). Evidence from 608 a proglacial fjord record in Nordauslandet points to the rapid deposition of a glacial diamict between 5.8 
and 5.7 cal kyr BP (Kubischta et al., 2011). These reconstructions point to cooling conditions occurring

610 during the hiatus in Haklutuyvatnet and the deposition of Unit C1 in Gjøavatnet.

611 Interestingly, several proxy reconstructions from the Fram Strait, just west of Amsterdamoya

612 (Figure 1), suggest there was warm and saline water in the subsurface ocean ( depth of $100 \mathrm{~m})$ during

613 this time (Müller et al., 2012; Werner et al., 2013; 2015; Aagaard-Sorensen et al., 2014). Two proxies for

614 sub-surface seawater temperature from core MSM5/5-712-2 depict warm temperatures from 6.1 to $5.2 \mathrm{ka}$

615 (Werner et al., 2013; Aagard-Sorensen et al., 2014) (Figure 11). The warm, saline water is presumed to

616 be Atlantic-sourced water carried by the WSC. Werner et al. (2013) attribute the subsurface temperature

617 increase to insulation by meltwater that limited heat loss to the atmosphere; if correct, these hydrographic

618 conditions suggest an increased amount of cold, fresh meltwater (and also associated sea ice) near

619 Amsterdamøya during this time. The subsurface warmth is not a feature of all temperature records from

620 the Fram Strait, however. The foram-based subsurface temperature reconstruction from nearby core

621 MSM5/5-723-2 (Werner et al., 2015) instead suggests that a broad cooling trend began around 6 kyr BP.

$6226 \mathrm{kyr}$ BP also marks the beginning of a decline in both the concentration of subpolar planktic forams and

623 reconstructed subsurface (75m depth) temperatures in the Kongsfjorden Trough (Rasmussen et al., 2014).

624 Local sea ice reconstructions also do not support the notion of dramatic increases in sea ice in

625 eastern Fram Strait from $\sim 6-5$ kyr BP. IP 25 concentrations from cores MSM5/5-723-2 and MSM5/5-712-2

626 are broadly stable during this time, as are IRD concentrations (Figure 11) (Müller et al., 2012; Werner et

627 al., 2013, 2015). Interestingly, however, relatively high $\mathrm{IP}_{25}$ concentrations are found on the East

628 Greenland Shelf from $\sim 6.5-5.6 \mathrm{kyr} \mathrm{BP}$, the only extended period of high $\mathrm{IP}_{25}$ accumulation until $\sim 1.0 \mathrm{cal}$

629 kyr BP (Müller et al., 2012). Funder et al. (2011) also inferred increased export of multiyear sea ice out of

630 the Fram Strait after 6 kyr BP, based on driftwood deposits on the coast of East Greenland.

$631 \quad$ Further afield, numerous marine records from the north of Iceland also suggest dramatic changes

632 were occurring 6-5 cal kyr BP. Castañeda et al. (2004) and Knudsen et al. (2004) both cite cooling

633 trends beginning at 6.2 and $6.0 \mathrm{cal}$ kyr BP respectively, while the alkenone based SST record of Moosen

634 et al. (2015) shows a similar cooling trend beginning at this time (Figure 11). There is also evidence for 
an increase in sea ice concentrations north of Iceland beginning at 6.2 cal kyr BP(Cabedo-Sanz et al.,

636 2016). Risebrobrakken et al. (2011) cite $6 \mathrm{cal} \mathrm{kyr} \mathrm{BP}$ as the end of the Holocene Thermal Maximum in

637 the North Atlantic, based on 6 cores from the Nordic and Barents Seas. Further south in the Atlantic basin

638 Hoogakker et al. (2011) suggest $6.5 \mathrm{cal}$ kyr BP was the start of a major reorganization of water masses

639 associated with deep ocean circulation. Our C1 subunit also aligns with the largest so-called Bond Event

640 of the Holocene (Bond Event \#4) identified in a marine record in the North Atlantic (Bond, 2001) (Figure

641 11).

642 Although there is not a clear relationship between these offshore records and the timing of

643 subunits C2 (c. 2.7-2.2 kyr BP) and C3 (c. 1.7-1.5 kyr BP), the $\mathrm{IP}_{25}$ concentration record of Müller et al.

644 2012, shows the highest accumulation rates of $\mathrm{IP}_{25}$ in the entire record during subunit C3 (Figure 11). A

645 minor dip in LOI concentrations in Gjøavatnet at $\sim 3.2$ cal kyr BP, which is one of the most pronounced in

646 the Hakluytvatnet record (Gjerde et al., in press), does appear contemporaneous with a spike in IRD in the

647 record of Werner et al., (2013) as well. Similar to the 6-5 cal kyr BP interval, many of the marine records

648 from the Fram Strait suggest a warming of subsurface waters and an increase in meridional overturning

649 circulation after 3 ka (e.g. Berben et al., 2014; Rasmussen et al., 2013; Sarnthein et al., 2003; Werner et

650 al., 2015) while simultaneously suggesting increased sea ice cover at the surface (Müller et al., 2009;

651 2012; Werner et al., 2015).

652 In summary, it appears there is evidence for greater subsurface warming and increased Atlantic

653 advection around 6-5 kyr BP (Werner et al., 2013; 2015; Aagaard-Sorensen et al., 2014), as well as

654 increased sea ice concentrations in the western part of the Fram Strait (Müller et al., 2012, Funder et al.,

655 2011), when we infer cold conditions on Amsterdamøya. The agreement between the end of unit $\mathrm{C} 1$ in

656 Gjøavatnet and the resumption of sedimentation in nearby Haklutuyvatnet also points to a wider forcing

657 beyond the lake catchment itself. We propose similar oceanographic conditions may have existed during

658 the deposition of subunits C2 and C3.

659 


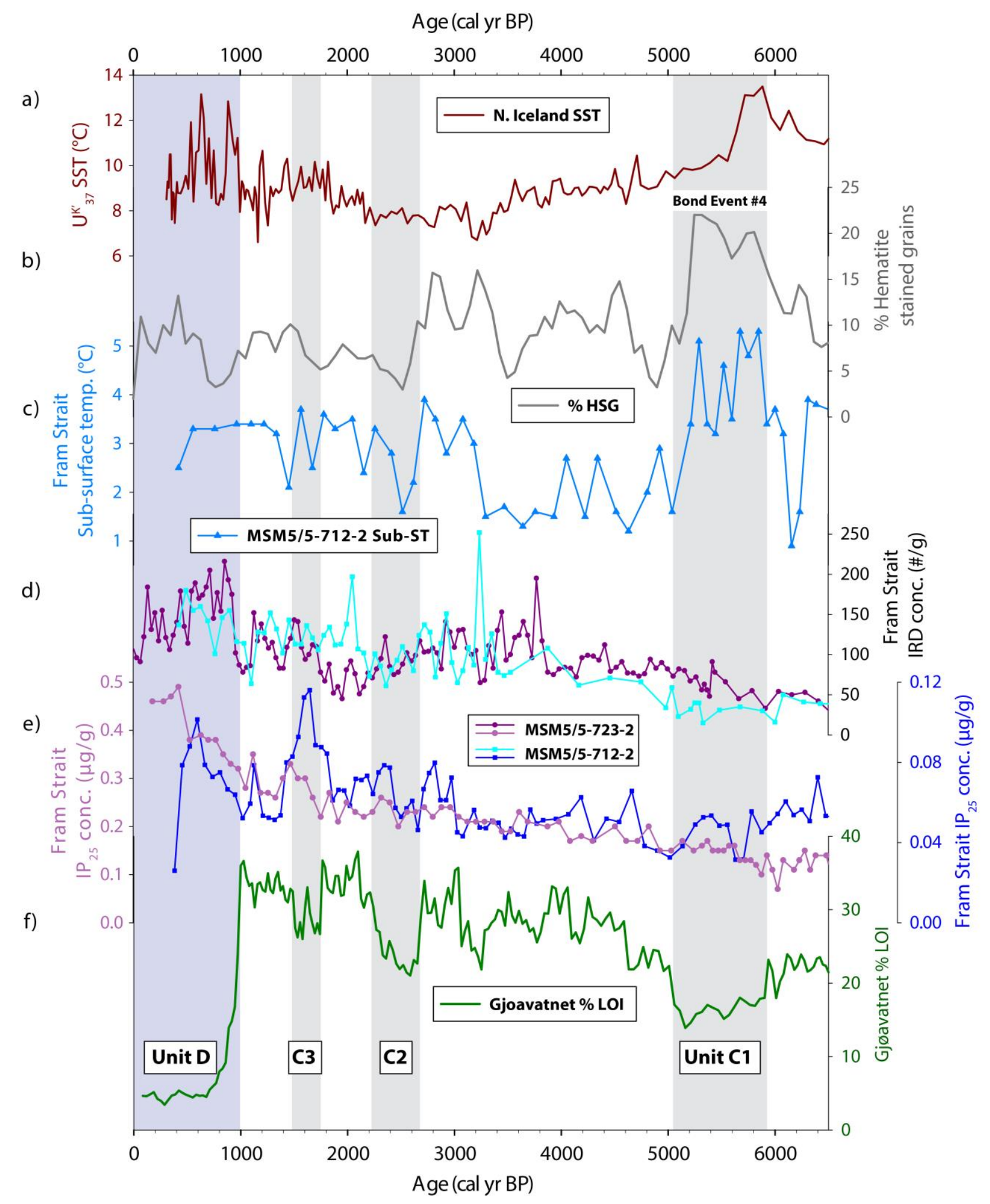

Figure 11: Compilation of relevant paleoclimate data from NW Svalbard, Fram Strait, and Davis Strait: a) Alkenone based sea-surface temperatures from NW Icelandic shelf (Moossen et al., 2015); b) \% hematite stained grains from core VM29-191 as a proxy for drift ice, w/ Bond Event \#4 labeled (Bond et 664 al., 2001); c) sub-surface ( 100m depth) foram-based temperatures from core MSM5/5-712-2 (Werner et 
al., 2013); d) IRD counts and e) $\mathrm{IP}_{25}$ concentrations from core MSM5/5-712-2 (cyan/blue square data points) (Werner et al., 2013) and MSM5/5-723-2 (purple circle data points) (Werner et al., 2015) from Fram Strait; f) \% loss-on-ignition data (green) from Gjøavatnet lake. Background shaded colors refer to sedimentary units from Gjøavatnet record (Figure 7).

\section{3) Late Holocene advance of Annabreen glacier}

The sediment record from Gjøavatnet clearly indicates that input of minerogenic material, formed by bedrock erosion by the Annabreen glacier, abruptly began again $\sim 1.0 \mathrm{cal} \mathrm{kyr} \mathrm{BP}$, and that this input has continued up to the present day. Other terrestrial records also suggest glaciers began to regrow around Svalbard around this time (Humlum et al., 2005; Snyder et al., 2000; van der Bilt et al., 2015), although Karlbreen on Mitrahalvøya appears to have begun to re-advance earlier ( 3.5 cal kyr BP) (Røthe et al., 2015). Linnebreen also began to regrow much earlier in the Holocene ( 4-5 cal kyr BP), but is believed to have reached its maximum Holocene extent during the $18-19^{\text {th }}$ centuries (Svendsen and Mangerud, 1997). Offshore marine records also suggest broad cooling conditions $\sim 1.0$ cal kyr BP. Werner et al. (2015) posit that elevated advection of North Atlantic waters into the eastern Fram Strait region likely ended around 1.0 kyr BP. Evidence for seasonal sea ice and unstable oceanographic conditions was found south of Svalbard in the western Barents Sea after 1.1 kyr BP (Berben et al., 2014) and Hald et al. (2004) point to a peak in IRD off western Svalbard at $0.8 \mathrm{cal}$ kyr BP.

It remains unclear whether colder summer temperatures or increased wintertime precipitation led to the reemergence of Annabreen. Temperature reconstructions from Kongressvatnet (D'Andrea et al., 2012), as well as from Lake Skardtjørna (Velle et al., 2011), both on western Svalbard, suggest that summer temperatures were relatively stable during the past 1800 years, prior to recent anthropogenic warming.

\section{6) Conclusions}

This paper reports a Holocene reconstruction of the Annabreen glacier from Lake Gjøavatnet on Amsterdamøya, NW Svalbard. We show that sedimentation was dominated by glacial activity in the catchment during the early and late Holocene and likely responded to regional-scale oceanographic 
changes in the intervening period. The early Holocene interval in Gjøavatnet is characterized by a two -

694 phase sedimentation history, with Annabreen retreating out of the lake basin $~ 11.1 \mathrm{kyr}$ BP and shrinking

695 to its minimum Holocene extent by $\sim 8.4 \mathrm{kyr}$ BP. During the period from $\sim 8.4-1.0$ cal kyr BP it seems

696 likely there was no glacial influence on sedimentation in Gjøavatnet. The organic-rich sediments

697 deposited during this time are interrupted by at least three intervals of lower organic matter content (c.

698 5.9-5.0 kyr BP, $2.6-2.2 \mathrm{kyr} \mathrm{BP}$, and $1.7-1.5 \mathrm{kyr} \mathrm{BP})$. We interpret the reductions in organic carbon

699 content as periods of more extensive summer lake ice cover (due to colder summer conditions) related to

700 changing oceanographic conditions in Fram Strait. At c. 1.0 cal kyr BP Annabreen re-advanced to the

701 extent that it dominated sedimentation in the lake.

702 Maritime lakes in places like Svalbard provide the opportunity to capture both local glacier

703 fluctuations along with offshore oceanographic conditions. Marine records are generally lower resolution

704 than their lacustrine counterparts, and incorporate information from the entire water column, potentially

705 complicating the detection of short-lived oceanographic events. Ocean based reconstructions over the

706 Holocene near Svalbard suggest a complex and variable water mass and climate history, which we

707 propose can be informed by the high-resolution lacustrine record from Gjøavatnet. While more research

708 from both the terrestrial and marine realms would help confirm the climate patterns identified here, this

709 study provides a unique record of both local glacial fluctuations and offshore oceanographic conditions

710 spanning the Holocene.

711

712

713 Acknowledgments

Permission to perform field work in this region of Svalbard was granted by the Governor of

715 Svalbard (RIS ID 5155, ref: 2012/00753-11 a.512). We thank Marthe Gjerde, Willem van der Bilt, and

716 Sædis Ólafsdóttir for assistance with field work and Marthe and Willem for discussions on the

717 manuscript. We also thank two anonymous reviewers for their constructive comments. Funding was

718 provided by the Svalbard Science Forum (AFG project no. 235919) as well as the Norwegian Research 
Council via the SHIFTS project. We thank Eivind Storen and Jordan Donn Holl for laboratory assistance at the University of Bergen, and Nicole DeRoberts for laboratory assistance at Lamont Doherty Earth

Observatory.

\section{References}

Aagaard-Sørensen, S., Husum, K., Hald, M., Marchitto, T., Godtliebsen, F., 2014. Sub sea surface temperatures in the Polar North Atlantic during the Holocene: Planktic foraminiferal $\mathrm{Mg} / \mathrm{Ca}$ temperature reconstructions. The Holocene 24, 93-103.

Alley, R.B., Mayewski, P.A., Sowers, T., Stuiver, M., Taylor, K.C., Clark, P.U., 1997. Holocene climatic instability: A prominent, widespread event 8200 yr ago. Geology 25, 483. doi:10.1130/00917613(1997)025<0483:HCIAPW>2.3.CO;2

Antoniades, D., 2008. Diatoms of North America: The freshwater floras of Prince Patrick, Ellef Ringnes and northern Ellesmere Islands from the Canadian Arctic Archipelago.

Bakke, J., Trachsel, M., Kvisvik, B.C., Nesje, A., Lyså, A., 2013. Numerical analyses of a multi-proxy data set from a distal glacier-fed lake, Sørsendalsvatn, western Norway. Quat. Sci. Rev. 73, 182195. doi:10.1016/j.quascirev.2013.05.003

Balascio, N.L., D’Andrea, W.J., Bradley, R.S., 2015. Glacier response to North Atlantic climate variability during the Holocene. Clim. Past 11, 1587-1598. doi:10.5194/cp-11-1587-2015

Balascio., N.L., D'Andrea, W.J., Gjerde, M., Bakke, J., Bradley, R.S., in press. Leaf wax hydrogen isotope reconstruction of hydroclimate changes during the Holocene on Amsterdamøya, Svalbard. Quat. Sci. Rev. http:dx.doi.org/10.1016/j.quascirev.2016.11.036

Belt, S.T., Massé, G., Rowland, S.J., Poulin, M., Michel, C., LeBlanc, B., 2007. A novel chemical fossil of palaeo sea ice: IP25. Org. Geochem. 38, 16-27. doi:10.1016/j.orggeochem.2006.09.013

Berben, S.M.P., Husum, K., Cabedo-Sanz, P., Belt, S.T., 2014. Holocene sub-centennial evolution of Atlantic water inflow and sea ice distribution in the western Barents Sea. Clim. Past 10, 181-198. doi:10.5194/cp-10-181-2014

Birks, H.J.B., Jones, V.J., Rose, N.L., 2004. Recent environmental change and atmospheric contamination on Svalbard as recorded in lake sediments-synthesis and general conclusions. J. Paleolimnol. 31, 531-546.

Blaauw, M., 2010. Methods and code for "classical" age-modelling of radiocarbon sequences. Quat. Geochronol. 5, 512-518. doi:10.1016/j.quageo.2010.01.002

Blake, W., 2006. Occurrence of the Mytilus edulis complex on Nordaustlandet, Svalbard: radiocarbon ages and climatic implications. Polar Res. 25, 123-137.

Bond, G., 2001. Persistent Solar Influence on North Atlantic Climate During the Holocene. Science 294, 2130-2136. doi:10.1126/science. 1065680

Briner, J.P., McKay, N.P., Axford, Y., Bennike, O., Bradley, R.S., de Vernal, A., Fisher, D., Francus, P., Fréchette, B., Gajewski, K., Jennings, A., Kaufman, D.S., Miller, G., Rouston, C., Wagner, B., 2016. Holocene climate change in Arctic Canada and Greenland. Quat. Sci. Rev. 147, 340-364. doi:10.1016/j.quascirev.2016.02.010

Cabedo-Sanz, P., Belt, S.T., Jennings, A.E., Andrews, J.T., Geirsdóttir, Á., 2016. Variability in drift ice export from the Arctic Ocean to the North Icelandic Shelf over the last 8000 years: A multi-proxy evaluation. Quat. Sci. Rev. 146, 99-115. doi:10.1016/j.quascirev.2016.06.012

Callaghan, T.V., Bergholm, F., Christensen, T.R., Jonasson, C., Kokfelt, U., Johansson, M., 2010. A new climate era in the sub-Arctic: Accelerating climate changes and multiple impacts: CHANGING CLIMATE IN THE SUB-ARCTIC. Geophys. Res. Lett. 37, n/a-n/a. doi:10.1029/2009GL042064 
Castañeda, I.S., Smith, L.M., Kristjánsdóttir, G.B., Andrews, J.T., 2004. Temporal changes in Holocene $\delta 180$ records from the northwest and central North Iceland Shelf. J. Quat. Sci. 19, 321334. doi:10.1002/jqs.841

D’Andrea, W.J., Vaillencourt, D.A., Balascio, N.L., Werner, A., Roof, S.R., Retelle, M., Bradley, R.S., 2012. Mild Little Ice Age and unprecedented recent warmth in an 1800 year lake sediment record from Svalbard. Geology 40, 1007-1010. doi:10.1130/G33365.1

Dean, W.E., 1974. Determination of carbonate and organic matter in calcareous sediments and sedimentary rocks by loss on ignition: comparison with other methods. Journal of Sedimentary Research 44.

Ebbesen, H., Hald, M., Eplet, T.H., 2007. Lateglacial and early Holocene climatic oscillations on the western Svalbard margin, European Arctic. Quat. Sci. Rev. 26, 1999-2011. doi:10.1016/j.quascirev.2006.07.020

Førland, E.J., Benestad, R., Hanssen-Bauer, I., Haugen, J.E., Skaugen, T.E., 2011. Temperature and Precipitation Development at Svalbard 1900-2100. Adv. Meteorol. 2011, 1-14. doi:10.1155/2011/893790

Forman, S.L., 1990. Post-glacial relative sea-level history of northwestern Spitsbergen, Svalbard. Geol. Soc. Am. Bull. 102, 1580-1590.

Forwick, M., Vorren, T.O., 2009. Late Weichselian and Holocene sedimentary environments and ice rafting in Isfjorden, Spitsbergen. Palaeogeogr. Palaeoclimatol. Palaeoecol. 280, 258-274. doi:10.1016/j.palaeo.2009.06.026

Funder, S., Goosse, H., Jepsen, H., Kaas, E., Kjaer, K.H., Korsgaard, N.J., Larsen, N.K., Linderson, H., Lysa, A., Moller, P., Olsen, J., Willerslev, E., 2011. A 10,000-Year Record of Arctic Ocean SeaIce Variability--View from the Beach. Science 333, 747-750. doi:10.1126/science.1202760

Gjermundsen, E.F., Briner, J.P., Akçar, N., Salvigsen, O., Kubik, P., Gantert, N., Hormes, A., 2013. Late Weichselian local ice dome configuration and chronology in Northwestern Svalbard: early thinning, late retreat. Quat. Sci. Rev. 72, 112-127. doi:10.1016/j.quascirev.2013.04.006

Gjerde, M., Bakke, J., D'Andrea, W.J., Balascio, N.L., Bradley, R., Vasskog, K., Ólafsdóttir, S., Røthe, T., Perren, B.B., Hormes, A., in press. Holocene multi-proxy environmental reconstruction from Lake Hakluytvatnet, Amsterdamøya Island, Svalbard (79.5 $\left.{ }^{\circ} \mathrm{N}\right)$ Quat. Sci Rev., http://dx.doi.org/10.1016/j.quascirev.2017.02.017.

Hald, M., Andersson, C., Ebbesen, H., Jansen, E., Klitgaard-Kristensen, D., Risebrobakken, B., Salomonsen, G.R., Sarnthein, M., Sejrup, H.P., Telford, R.J., 2007. Variations in temperature and extent of Atlantic Water in the northern North Atlantic during the Holocene. Quat. Sci. Rev. 26, 3423-3440. doi:10.1016/j.quascirev.2007.10.005

Hald, M., Ebbesen, H., Forwick, M., Godtliebsen, F., Khomenko, L., Korsun, S., Ringstad Olsen, L., Vorren, T.O., 2004. Holocene paleoceanography and glacial history of the West Spitsbergen area, Euro-Arctic margin. Quat. Sci. Rev. 23, 2075-2088. doi:10.1016/j.quascirev.2004.08.006

Hammarlund, D., 1993. A distinct $\delta 13 \mathrm{C}$ decline in organic lake sediments at the Pleistocene-Holocene transition in southern Sweden. Boreas 22, 236-243.

Heiri, O., Lotter, A.F., Lemcke, G., 2001. Loss on ignition as a method for estimating organic and carbonate content in sediments: reproducibility and comparability of results. J. Paleolimnol. 25, $101-110$.

Hjelle, A., Ohta, Y., 1974. Contribution to the geology of north western Spitsbergen. Norsk Polarinstitutt Skrifter, v. 158, 1-107.

Hoogakker, B.A.A., Chapman, M.R., McCave, I.N., Hillaire-Marcel, C., Ellison, C.R.W., Hall, I.R., Telford, R.J., 2011. Dynamics of North Atlantic Deep Water masses during the Holocene: HOLOCENE N ATLANTIC DEEP WATER DYNAMICS. Paleoceanography 26. doi:10.1029/2011PA002155

Hormes, A., Gjermundsen, E.F., Rasmussen, T.L., 2013. From mountain top to the deep sea Deglaciation in 4D of the northwestern Barents Sea ice sheet. Quat. Sci. Rev. 75, 78-99. doi:10.1016/j.quascirev.2013.04.009 
Humlum, O., Elberling, B., Hormes, A., Fjordheim, K., Hansen, O.H., Heinemeier, J., 2005. LateHolocene glacier growth in Svalbard, documented by subglacial relict vegetation and living soil microbes. The Holocene 15, 396-407.

Ingólfsson, Ó., Landvik, J.Y., 2013. The Svalbard-Barents Sea ice-sheet - Historical, current and future perspectives. Quat. Sci. Rev. 64, 33-60. doi:10.1016/j.quascirev.2012.11.034

Johnsen, S.J., Dahl-Jensen, D., Gundestrup, N., Steffensen, J.P., Clausen, H.B., Miller, H., MassonDelmotte, V., Sveinbjornsdottir, A.E., White, J., 2001. Oxygen isotope and palaeotemperature records from six Greenland ice-core stations: Camp Century, Dye-3, GRIP, GISP2, Renland and NorthGRIP. J. Quat. Sci. 16, 299-307. doi:10.1002/jqs.622

Kaplan, M.R., Wolfe, A.P., 2006. Spatial and temporal variability of Holocene temperature in the North Atlantic region. Quat. Res. 65, 223-231. doi:10.1016/j.yqres.2005.08.020

Kaufman, D.S., Ager, T.A., Anderson, N.J., Anderson, P.M., Andrews, J.T., Bartlein, P.J., Brubaker, L.B., Coats, L.L., Cwynar, L.C., Duvall, M.L., others, 2004. Holocene thermal maximum in the western Arctic (0-180 W). Quat. Sci. Rev. 23, 529-560.

Knudsen, K.., Jiang, H., Jansen, E., Eiríksson, J., Heinemeier, J., Seidenkrantz, M.-S., 2004. Environmental changes off North Iceland during the deglaciation and the Holocene: foraminifera, diatoms and stable isotopes. Mar. Micropaleontol. 50, 273-305. doi:10.1016/S03778398(03)00075-6

Kubischta, F., Knudsen, K.L., Ojala, A.E., SALONEN, V.-P., 2011. HOLOCENE BENTHIC FORAMINIFERAL RECORD FROM A HIGH-ARCTIC FJORD, NORDAUSTLANDET, SVALBARD. Geogr. Ann. Ser. Phys. Geogr. 93, 227-242.

Landvik, J.Y., Bondevik, S., Elverhøi, A., Fjeldskaar, W., Mangerud, J., Salvigsen, O., Siegert, M.J., Svendsen, J.-I., Vorren, T.O., 1998. The last glacial maximum of Svalbard and the Barents Sea area: ice sheet extent and configuration. Quat. Sci. Rev. 17, 43-75.

Landvik, J.Y., Brook, E.J., Gualtieri, L., Raisbeck, G., Salvigsen, O., Yiou, F., 2003. Northwest Svalbard during the last glaciation: Ice-free areas existed. Geology 31, 905-908.

Laskar, J., Robutel, P., Joutel, F., Gastineau, M., Correia, A.C.M., Levrard, B., others, 2004. A long-term numerical solution for the insolation quantities of the Earth. Astron. Astrophys. 428, 261-285.

Mayewski, P.A., Rohling, E.E., Curt Stager, J., Karlén, W., Maasch, K.A., David Meeker, L., Meyerson, E.A., Gasse, F., van Kreveld, S., Holmgren, K., Lee-Thorp, J., Rosqvist, G., Rack, F., Staubwasser, M., Schneider, R.R., Steig, E.J., 2004. Holocene climate variability. Quat. Res. 62, 243-255. doi:10.1016/j.yqres.2004.07.001

Meyers, P.A., 1997. Organic geochemical proxies of paleoceanographic, paleolimnologic, and paleoclimatic processes. Org. Geochem. 27, 213-250.

Miller, G.H., Brigham-Grette, J., Alley, R.B., Anderson, L., Bauch, H.A., Douglas, M.S.V., Edwards, M.E., Elias, S.A., Finney, B.P., Fitzpatrick, J.J., Funder, S.V., Herbert, T.D., Hinzman, L.D., Kaufman, D.S., MacDonald, G.M., Polyak, L., Robock, A., Serreze, M.C., Smol, J.P., Spielhagen, R., White, J.W.C., Wolfe, A.P., Wolff, E.W., 2010. Temperature and precipitation history of the Arctic. Quat. Sci. Rev. 29, 1679-1715. doi:10.1016/j.quascirev.2010.03.001

Moossen, H., Bendle, J., Seki, O., Quillmann, U., Kawamura, K., 2015. North Atlantic Holocene climate evolution recorded by high-resolution terrestrial and marine biomarker records. Quat. Sci. Rev. 129, 111-127. doi:10.1016/j.quascirev.2015.10.013

Müller, J., Massé, G., Stein, R., Belt, S. 2009. Variability of sea-ice conditions in the Fram Strait over the past 30,000 years. Nature Geoscience 2, 772-776.

Müller, J., Werner, K., Stein, R., Fahl, K., Moros, M., Jansen, E., 2012. Holocene cooling culminates in sea ice oscillations in Fram Strait. Quat. Sci. Rev. 47, 1-14. doi:10.1016/j.quascirev.2012.04.024

Ohta, Y., Hjelle, A., Dallmann, W.K. (eds.) 2007: Geological map Svalbard 1:100 000, sheet A4G, Vasahalvøya. Norsk Polarinstitutt Temakart nr. 40.

Perren, B.B., Massa, C., Bichet, V., Gauthier, É., Mathieu, O., Petit, C., Richard, H., 2012. A paleoecological perspective on 1450 years of human impacts from a lake in southern Greenland. The Holocene 22, 1025-1034. 
866

867

868

869

870

871

872

873

874

875

876

877

878

879

880

881

882

883

884

885

886

887

888

889

890

891

892

893

894

895

896

897

898

899

900

901

902

903

904

905

906

907

908

909

910

911

912

913

914

915

Rasmussen, T.L., Forwick, M., Mackensen, A., 2013. Reprint of: Reconstruction of inflow of Atlantic Water to Isfjorden, Svalbard during the Holocene: Correlation to climate and seasonality. Mar. Micropaleontol. 99, 18-28. doi:10.1016/j.marmicro.2013.03.011

Rasmussen, T.L., Thomsen, E., Skirbekk, K., Ślubowska-Woldengen, M., Klitgaard Kristensen, D., Koç, N., 2014. Spatial and temporal distribution of Holocene temperature maxima in the northern Nordic seas: interplay of Atlantic-, Arctic- and polar water masses. Quat. Sci. Rev. 92, 280-291. doi:10.1016/j.quascirev.2013.10.034

Reimer, P.J., Bard, E., Bayliss, A., Beck, J.W., Blackwell, P.G., Ramsey, C.B., Buck, C.E., Cheng, H., Edwards, R.L., Friedrich, M., others, 2013. IntCal13 and Marine13 radiocarbon age calibration curves 0-50,000 years cal BP. Radiocarbon 55, 1869-1887.

Renberg, I., 1990. A procedure for preparing large sets of diatom slides from sediment cores. J. Paleolimnol. 4, 87-90.

Reusche, M., Winsor, K., Carlson, A.E., Marcott, S.A., Rood, D.H., Novak, A., Roof, S., Retelle, M., Werner, A., Caffee, M., Clark, P.U., 2014. 10Be surface exposure ages on the late-Pleistocene and Holocene history of Linnébreen on Svalbard. Quat. Sci. Rev. 89, 5-12. doi:10.1016/j.quascirev.2014.01.017

Risebrobakken, B., Dokken, T., Smedsrud, L.H., Andersson, C., Jansen, E., Moros, M., Ivanova, E.V., 2011. Early Holocene temperature variability in the Nordic Seas: The role of oceanic heat advection versus changes in orbital forcing: EARLY HOLOCENE ADVECTION VS. INSOLATION. Paleoceanography 26. doi:10.1029/2011PA002117

Rohling, E.J., Pälike, H., 2005. Centennial-scale climate cooling with a sudden cold event around 8,200 years ago. Nature 434, 975-979.

Røthe, T.O., Bakke, J., Vasskog, K., Gjerde, M., D’Andrea, W.J., Bradley, R.S., 2015. Arctic Holocene glacier fluctuations reconstructed from lake sediments at Mitrahalvøya, Spitsbergen. Quat. Sci. Rev. 109, 111-125. doi:10.1016/j.quascirev.2014.11.017

Salvigsen, O., 2002. Radiocarbon-dated Mytilus edulis and Modiolus modiolus from northern Svalbard: Climatic implications. Nor. Geogr. Tidsskr. - Nor. J. Geogr. 56, 56-61. doi:10.1080/002919502760056350

Salvigsen, O., Forman, S.L., Miller, G.H., 1992. Thermophilous molluscs on Svalbard during the Holocene and their paleoclimatic implications. Polar Res. 11, 1-10.

Sarnthein, M., Kreveld, S., Erlenkeuser, H., Grootes, P., Kucera, M., Pflaumann, U., Schulz, M., 2003. Centennial-to-millennial-scale periodicities of Holocene climate and sediment injections off the western Barents shelf, 75 N. Boreas 32, 447-461.

Sejrup, H.P., Seppä, H., McKay, N.P., Kaufman, D.S., Geirsdóttir, Á., de Vernal, A., Renssen, H., Husum, K., Jennings, A., Andrews, J.T., 2016. North Atlantic-Fennoscandian Holocene climate trends and mechanisms. Quat. Sci. Rev. 147, 365-378. doi:10.1016/j.quascirev.2016.06.005

Serreze, M.C., Barry, R.G., 2011. Processes and impacts of Arctic amplification: A research synthesis. Glob. Planet. Change 77, 85-96. doi:10.1016/j.gloplacha.2011.03.004

Skirbekk, K., Kristensen, D.K., Rasmussen, T.L., Koç, N., Forwick, M., 2010. Holocene climate variations at the entrance to a warm Arctic fjord: evidence from Kongsfjorden trough, Svalbard. Geol. Soc. Lond. Spec. Publ. 344, 289-304.

Ślubowska, M.A., Koç, N., Rasmussen, T.L., Klitgaard-Kristensen, D., 2005. Changes in the flow of Atlantic water into the Arctic Ocean since the last deglaciation: Evidence from the northern Svalbard continental margin, $80^{\circ} \mathrm{N}$ : ATLANTIC WATER INFLOW INTO ARCTIC OCEAN. Paleoceanography 20, n/a-n/a. doi:10.1029/2005PA001141

Ślubowska, M.A., Rasmussen, T.L., Koç, N., Klitgaard-Kristensen, Nilsen, F., Solheim, A., 2007. Advection of Atlantic Water to the western and northern Svalbard shelf since 17,500 cal yr BP. Quaternary Science Reviews 26, 463-478.

Snyder, J.A., Werner, A., Miller, G.H., 2000. Holocene cirque glacier activity in western Spitsbergen, Svalbard: sediment records from proglacial Linnévatnet. The Holocene 10, 555-563. 
Stocker, T.F., Qin, D., Plattner, G.-K., Tignor, M., Allen, S.K., Boschung, J., Nauels, A., Xia, Y., Bex, V., Midgley, P.M., 2013. Climate change 2013: The physical science basis. Intergov. Panel Clim. Change Work. Group Contrib. IPCC Fifth Assess. Rep. AR5Cambridge Univ Press N. Y. Svendsen, J.I., Mangerud, J., 1997. Holocene glacial and climatic variations on Spitsbergen, Svalbard. The Holocene 7, 45-57.

Thomas, E.R., Wolff, E.W., Mulvaney, R., Steffensen, J.P., Johnsen, S.J., Arrowsmith, C., White, J.W.C., Vaughn, B., Popp, T., 2007. The 8.2ka event from Greenland ice cores. Quat. Sci. Rev. 26, 7081. doi:10.1016/j.quascirev.2006.07.017

van der Bilt, W.G.M., Bakke, J., Vasskog, K., D’Andrea, W.J., Bradley, R.S., Ólafsdóttir, S., 2015. Reconstruction of glacier variability from lake sediments reveals dynamic Holocene climate in Svalbard. Quat. Sci. Rev. 126, 201-218. doi:10.1016/j.quascirev.2015.09.003

van der Bilt, W.G.M., D’Andrea, W.J., Bakke, J., Balascio, N.L., Werner, J.P., Gjerde, M., Bradley, R.S., 2016. Alkenone-based reconstructions reveal four-phase Holocene temperature evolution for High Arctic Svalbard. Quat. Sci. Rev. doi:10.1016/j.quascirev.2016.10.006

Velle, G., Kongshavn, K., Birks, H.J.B., 2011. Minimizing the edge-effect in environmental reconstructions by trimming the calibration set: Chironomid-inferred temperatures from Spitsbergen. The Holocene 21, 417-430. doi:10.1177/0959683610385723

Werner, K., Müller, J., Husum, K., Spielhagen, R.F., Kandiano, E.S., Polyak, L., 2015. Holocene sea subsurface and surface water masses in the Fram Strait - Comparisons of temperature and sea-ice reconstructions. Quat. Sci. Rev. doi:10.1016/j.quascirev.2015.09.007

Werner, K., Spielhagen, R.F., Bauch, D., Hass, H.C., Kandiano, E., 2013. Atlantic Water advection versus sea-ice advances in the eastern Fram Strait during the last 9 ka: Multiproxy evidence for a two-phase Holocene: HOLOCENE IN EASTERN FRAM STRAIT. Paleoceanography 28, 283295. doi: $10.1002 /$ palo. 20028

Wojtal, A.Z., Ognjanova-Rumenova, N., Wetzel, C.E., Hinz, F., Piatek, J., Kapetanovic, T., Ector, L., Buczko, K., 2014. Diversity of the genus Genkalia (Bacillariophyta) in boreal and mountain lakes-taxonomy, distribution and ecology. Fottea 14, 225-239. 